\title{
Observation of biogenic secondary organic aerosols in the atmosphere of a mountain site in central China: temperature and relative humidity effects
}

\author{
J. J. Li ${ }^{1}$, G. H. Wang ${ }^{1}$, J. J. Cao ${ }^{1}$, X. M. Wang ${ }^{2}$, and R. J. Zhang ${ }^{3}$ \\ ${ }^{1}$ State Key Laboratory of Loess and Quaternary Geology, Institute of Earth Environment, Chinese Academy of Sciences, \\ Xi'an 710075, China \\ ${ }^{2}$ State Key Laboratory of Organic Geochemistry, Guangzhou Institute of Geochemistry, Chinese Academy of Sciences, \\ Guangzhou 510640, China \\ ${ }^{3}$ Key Laboratory of Regional Climate-Environment for Temperate East Asia, Institute of Atmospheric Physics, Chinese \\ Academy of Sciences, Beijing 100029, China
}

Correspondence to: G. H. Wang (wanggh@ieecas.cn, gehuiwang@yahoo.com.cn)

Received: 6 May 2013 - Published in Atmos. Chem. Phys. Discuss.: 4 July 2013

Revised: 3 October 2013 - Accepted: 29 October 2013 - Published: 28 November 2013

\begin{abstract}
Secondary organic aerosols (SOA) derived from isoprene, pinene and caryophyllene were determined for $\mathrm{PM}_{10}$ and size-segregated (9-stages) aerosols collected at the summit (2060 m a.s.1.) of Mt. Hua, central China during the summer of 2009. Estimated concentrations of isoprene, $\alpha$ $/ \beta$-pinene and $\beta$-caryophyllene derived secondary organic carbon (SOC) are $81 \pm 53,29 \pm 14$ and $98 \pm 53 \mathrm{ng} \mathrm{m}^{-3}$, accounting for $2.7 \pm 1.0 \%, 0.8 \pm 0.2 \%$ and $2.1 \pm 1.0 \%$ of OC, respectively. Concentrations of biogenic (BSOA, the isoprene/pinene/caryophyllene oxidation products) and anthropogenic (ASOA, mainly aromatic acids) SOA positively correlated with temperature $(R=0.57-0.90)$. However, a decreasing trend of BSOA concentration with an increase in relative humidity $(\mathrm{RH})$ was observed during the sampling period, although a clear trend between ASOA and RH was not found. Based on the AIM Model calculation, we found that during the sampling period an increase in $\mathrm{RH}$ resulted in a decrease in the aerosol acidity and thus reduced the effect of acid-catalysis on BSOA formation. There was no significant correlation observed for the BSOA products and anthropogenic parameters (e.g. $\mathrm{EC}, \mathrm{SO}_{4}^{2-}$ and $\mathrm{NO}_{3}^{-}$). Size distribution measurements showed that most of the determined BSOA are formed in the aerosol phase and enriched in the fine mode $(<2.1 \mu \mathrm{m})$ except for cis-pinonic acid, which is formed in the gas phase and subsequently partitioned into aerosol phase and thus presents a bimodal pattern with a
\end{abstract}

small peak in the fine mode and a large peak in the coarse mode $(>2.1 \mu \mathrm{m})$.

\section{Introduction}

Volatile organic compounds (VOCs) produced from the biosphere have a substantial impact on the atmospheric chemistry. On a global scale, biogenic volatile organic compounds (BVOCs, $1150 \mathrm{Tg} \mathrm{yr}^{-1}$ ), mostly consisting of isoprene, monoterpenes (such as $\alpha$ - $/ \beta$-pinene) and sesquiterpenes (such as $\beta$-caryophyllene), are one order of magnitude more abundant than anthropogenic VOCs (Guenther et al., 2006). The high emission of BVOCs can significantly increase the abundance of secondary organic aerosols (SOA) in the atmosphere, which influences the atmospheric radiation budget directly by absorbing and scattering sun light and indirectly by acting as cloud condensation nuclei (CCN) (Kanakidou et al., 2005; Kawamura et al., 2005; Turpin and Huntzicker, 1995). Therefore, numerous studies in the last decade have been devoted to characterising biogenic secondary organic aerosols (BSOA) in the atmosphere (Claeys et al., 2004; Froyd et al., 2010; Jaoui et al., 2008; Kleindienst, 2009; Offenberg et al., 2009).

China is a large and diverse source of aerosols and trace gases to the atmosphere. Biogenic emissions are high in some 
forested areas of the country. For example, a model study showed that monthly average emission rates of isoprene are more than $30 \mathrm{mg} \mathrm{m}^{-2} \mathrm{day}^{-1}$ in southeastern, northeastern and central China in summer (Guenther et al., 2006). On the other hand, air pollution in China is serious (Fang et al., 2009; Wang et al., 2006). The North China Plain, Guanzhong Basin, and Sichuan Basin in the country are the three most heavily polluted regions in the world, where the annual level of $\mathrm{PM}_{2.5}$ on the ground surface was more than $80 \mu \mathrm{g} \mathrm{m}^{-3}$ during 2001-2006 (van Donkelaar et al., 2010). In the past decade, SOA derived from anthropogenic sources in China has been given much attention. However, BSOA in the country has only been documented by a limited number of studies (Ding et al., 2011; Fu et al., 2010; Hu et al., 2008; Wang et al., 2008) with no report of BSOA for the central regions of China. The atmospheric environment over mountainous areas is unique because of lower temperatures, higher humidity and stronger solar radiation, and thus chemical and physical properties of mountain aerosols differ from those in lowlands (e.g. urban area). Furthermore, mountainous areas are receptors for anthropogenic gas and aerosols originating from the lowlands by long-range transport. Thus, the characterisation of alpine BSOA can improve our understanding of physicochemical properties of aerosols in the atmosphere.

In the current paper, we first investigate molecular compositions of BSOA, including those derived from isoprene, pinene and caryophyllene, in airborne particles at the summit (2060 m altitude) of Mt. Hua in central China and their relationship with temperature and relative humidity. Then we measure their size distributions to identify the sources of BSOA in the alpine atmosphere.

\section{Experimental section}

\subsection{Sample collection}

Mt. Hua $\left(34^{\circ} 29^{\prime} \mathrm{N}, 110^{\circ} 05^{\prime} \mathrm{E}, 2060 \mathrm{~m}\right.$ a.s.l., Fig. 1) is located on the eastern border of the Qinling Mountain Range in central China, where there are around 3000 species of vegetation. The low-elevation forests of the foothills are dominated by temperate deciduous trees. At the middle elevations, conifers are mixed with broadleaf birch, oak and hornbeam. Fir, cunninghamia, and birch are dominant species of the high-elevation forests (Fu et al., 1996). Collection of $\mathrm{PM}_{10}$ and size-segregated particles was performed at the summit of Mt. Hua during the summer of 2009 (15 July-25 August). The samples of 22-25 July and 27-29 July were not collected because of power interruption. $\mathrm{PM}_{10}$ samples were collected using a medium-volume air sampler (KC-120H, made in China) at an airflow rate of $100 \mathrm{~L} \mathrm{~min}^{-1}$, while the size-segregated samples were collected using an Andersen 9stage air sampler (Thermo electronic Company, USA) with the cutoff points of 9.0, 5.8, 4.7, 3.3, 2.1, 1.1, 0.7, and $0.4 \mu \mathrm{m}$ under an airflow rate of $28.3 \mathrm{~L} \mathrm{~min}^{-1}$. A total of $34 \mathrm{PM}_{10}$

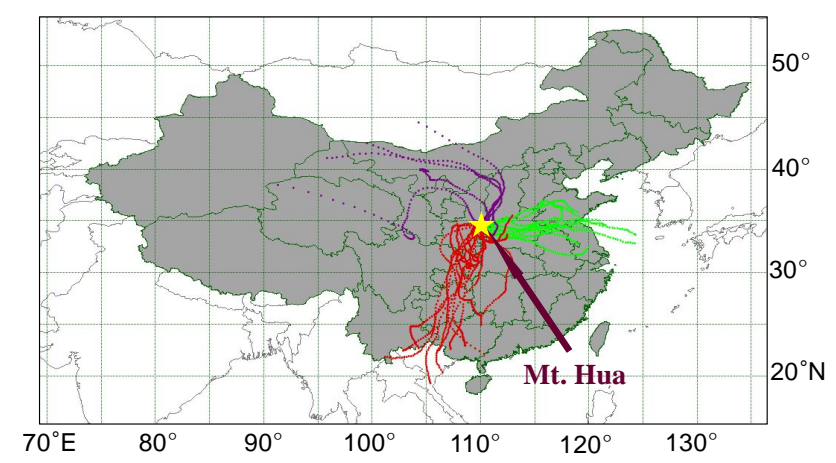

Fig. 1. Location of the sampling site (Mt. Hua; $34^{\circ} 29^{\prime} \mathrm{N}, 110^{\circ} 05^{\prime} \mathrm{E}$; $2060 \mathrm{~m}$ a.s.1.) and $72 \mathrm{~h}$ backward air mass trajectories reaching the summit during the sampling in the summer of 2009.

samples were collected over a $24 \mathrm{~h}$ period. The size-resolved aerosols (nine samples per set, three sets in total) were collected for 5-6 days in each set. All samples were collected on pre-baked $\left(450^{\circ}\right.$ for $8 \mathrm{~h}$ ) quartz microfibre filters (Whatman 42). After sampling, the filter was sealed in an aluminum bag and stored at $-18^{\circ}$ prior to analysis. Blank samples (three for $\mathrm{PM}_{10}$ and two sets for size-resolved aerosols) were collected before and after sampling by mounting the filters onto the sampler for about $10 \mathrm{~min}$ without pumping any air.

\subsection{Sample extraction, derivatization and GC/MS quantification}

Detailed methods for extraction, derivatization and gas chromatography/mass spectrometry (GC/MS) analysis were described elsewhere (Wang et al., 2006, 2009a). Briefly, one fourth of the sample/blank filter was cut and extracted with a mixture of dichloromethane and methanol $(2: 1, v / v)$ under ultrasonication ( $15 \mathrm{~min}$ each, repeated three times). The extracts were concentrated using a rotary evaporator under vacuum conditions and then dried using pure nitrogen. After reaction with a mixture of N,O-bis-(trimethylsilyl) trifluoroacetamide (BSTFA) and pyridine $(5: 1, v / v)$ at $70^{\circ}$ for $3 \mathrm{~h}$, the derivatives were determined using GC/MS as described below.

Gas chromatography-mass spectrometry (GC/MS) analysis of the derivatized fraction was performed using an Agilent 7890A GC coupled with an Agilent 5975C MSD. The GC separation was carried out using a DB-5MS fused silica capillary column with the GC oven temperature programmed from $50^{\circ}(2 \mathrm{~min})$ to $120^{\circ}$ at $15^{\circ} \mathrm{min}^{-1}$ and then to $300^{\circ}$ at $5^{\circ} \mathrm{min}^{-1}$ with a final isothermal hold at $300^{\circ}$ for $16 \mathrm{~min}$. The sample was injected in a splitless mode at an injector temperature of $280^{\circ}$, and scanned from 50 to 650 Daltons using electron impact (EI) mode at $70 \mathrm{eV}$. Chemical structures and possible sources of the $20 \mathrm{de}-$ tected organic compounds in this study are listed in Table 1 , while their $\mathrm{GC}$ retention times and $\mathrm{m} / \mathrm{z}$ ratios are 
Table 1. Chemical characters and possible sources of detected organic tracers.

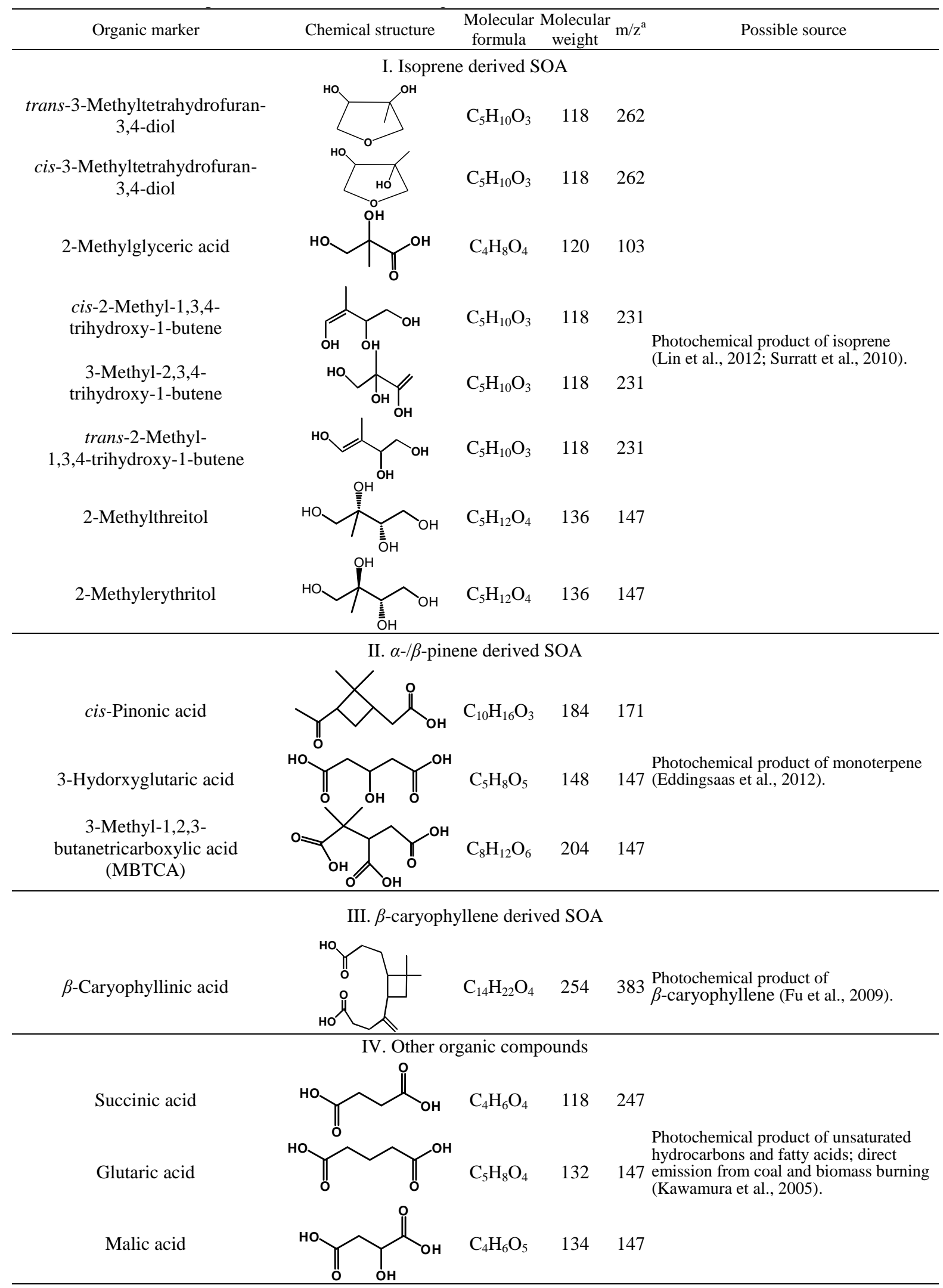


Table 1. Continued.

\begin{tabular}{|c|c|c|c|c|c|}
\hline Organic marker & Chemical structure & $\begin{array}{c}\text { Molecular } \\
\text { formula }\end{array}$ & $\begin{array}{c}\text { Molecular } \\
\text { weight }\end{array}$ & $\mathrm{m} / \mathrm{z}^{\mathrm{a}}$ & Possible source \\
\hline$o$-Phthalic acid & & $\mathrm{C}_{8} \mathrm{H}_{6} \mathrm{O}_{4}$ & 166 & 295 & $\begin{array}{l}\text { Photochemical product of toluene, } \\
\text { xylene, naphthalene and other } \\
\text { anthropogenic pollutants (Kawamura et } \\
\text { al., 2005). }\end{array}$ \\
\hline$m$-Phthalic acid & & $\mathrm{C}_{8} \mathrm{H}_{6} \mathrm{O}_{4}$ & 166 & 295 & \\
\hline$p$-Phthalic acid & & $\mathrm{C}_{8} \mathrm{H}_{6} \mathrm{O}_{4}$ & 166 & 295 & $\begin{array}{l}\text { Direct emission by open buring of new } \\
\text { plastic bags, roadside litter and landfill } \\
\text { trash; secondary formation (Kawamura } \\
\text { et al., 2005; Kawamura and Pavuluri, } \\
\text { 2010). }\end{array}$ \\
\hline Levoglucosan & & $\mathrm{C}_{6} \mathrm{H}_{10} \mathrm{O}_{5}$ & 162 & 217 & $\begin{array}{l}\text { Pyrolysis product of materials containing } \\
\text { cellulose (Li et al., 2012; Simoneit et al., } \\
\text { 2004a). }\end{array}$ \\
\hline Arabitol & & $\mathrm{C}_{5} \mathrm{H}_{12} \mathrm{O}_{5}$ & 152 & 217 & $\begin{array}{l}\text { Direct emission by microorganism, } \\
\text { plants and animals (Li et al., 2012; } \\
\text { Simoneit et al., 2004a). }\end{array}$ \\
\hline
\end{tabular}

a Mass-to-charge ratio of fragment ions for qualification and quantification.

shown in Fig. 2. All the detected compounds were quantified using the peak area of the individual characteristic ion. In addition, GC/MS response factors of cis-pinonic acid, succinic acid, glutaric acid, malic acid, phthalic acids, levoglucosan and arabitol were determined using authentic standards, while GC/MS response factors of 3-MeTHF3,4-diols (trans-3-methyltetrahydrofuran-3,4-diol and cis3-methyltetrahydrofuran-3,4-diol), $\mathrm{C}_{5}$-alkene triols (cis-2methyl-1,3,4-trihydoxy-1-butane, 3-methyl-2,3,4-trihydoxy1-butane and trans-2-methyl-1,3,4-trihydoxy-1-butane), and 2-methyltetrols (2-methylthreitol and 2-methylerythritol) were replaced by that of erythritol, and response factors of 2methylglyceric acid, 3-hydroxyglutaric acid, 3-methyl-1,2,3butanetricarboxylic acid and $\beta$-caryophyllinic acid were replaced by those of glyceric acid, tartaric acid, suberic acid and cis-pinic acid, respectively, because the authentic standards are not commercially available. No significant contamination ( $<10 \%$ of those in the samples) was found in the blanks. Average recoveries of the target compounds were better than $70 \%$. Compounds used in a recovery experiment are usually pure agents while those in real samples are a mixture with other organic and inorganic components, which means that the recovery experiment could not entirely reflect the conditions of target compounds in the atmosphere. Thus, data presented here were corrected for the field blanks but not corrected for the recoveries.

$\mathrm{OC}$ and $\mathrm{EC}$ in the $\mathrm{PM}_{10}$ samples were analysed using DRI Model 2001 Carbon analyser following the Interagency Monitoring of Protected Visual Environments (IMPROVE)

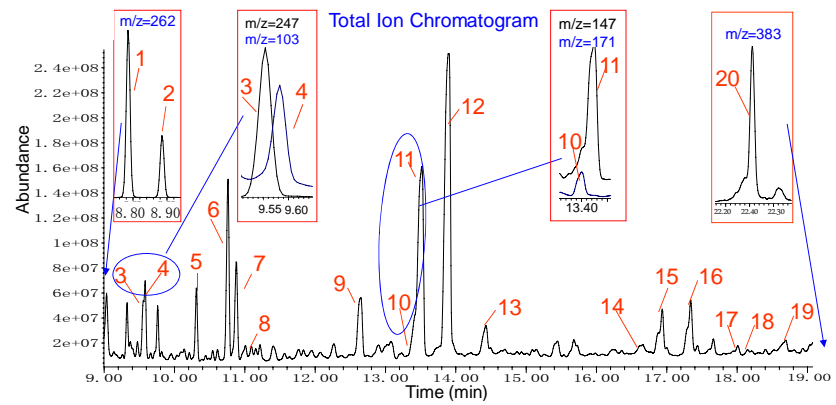

Fig. 2. GC/MS ion chromatography obtained for a trimethylsilylated $\mathrm{PM}_{10}$ sample collected on 15 August 2009 (1. trans-3methyltetrahydrofuran-3,4-diol; 2. cis-3-methyltetrahydrofuran3,4-diol; 3. succinic acid; 4. 2-methylglyceric acid; 5. cis-2-methyl1,3,4-trihydoxy-1-butane; 6. 3-methyl-2,3,4-trihydoxy-1-butane; 7. trans-2-methyl-1,3,4-trihydoxy-1-butane; 8. glutaric acid; 9. malic acid; 10. cis-pinonic acid; 11. 2-methylthreitol; 12. 2-methylerythritol; 13. 3-hydorxyglutaric acid; 14. o-phthalic acid; 15. levoglucosan; 16. arabitol; 17. 3-methyl-1,2,3butanetricarboxylic acid; 18. $m$-phthalic acid; 19. $p$-phthalic acid; 20. $\beta$-caryophyllinic acid).

thermal/optical reflectance (TOR) protocol (Chow et al., 2004). Inorganic ions including $\mathrm{SO}_{4}^{2-}, \mathrm{NO}_{3}^{-}$and $\mathrm{NH}_{4}^{+}$in $\mathrm{PM}_{10}$ and size-resolved samples were analysed using ion chromatography (Li et al., 2011; Shen et al., 2008). Particle in-situ $\mathrm{pH}\left(\mathrm{pH}_{\mathrm{IS}}\right)$ and aerosol liquid water content (LWC) were calculated by Aerosol Inorganic Model (AIM) using a 
$\mathrm{SO}_{4}^{2-}-\mathrm{NO}_{3}^{-}-\mathrm{NH}_{4}^{+}-\mathrm{H}^{+}$system (AIM-II) (Clegg et al., 1998a, b) (http://www.aim.env.uea.ac.uk/aim/aim.php). These data were used in the current study to explore the sources of BSOA.

\section{Results and discussion}

\subsection{Abundance of OC, EC and SOA in $\mathrm{PM}_{10}$}

\subsubsection{Overall results}

Table 2 summarizes the arithmetic mean concentrations and standard deviations of organic compounds, OC, EC and inorganic ions detected for the $\mathrm{PM}_{10}$ samples. Particle mass $\left(\mathrm{PM}_{10}\right), \mathrm{OC}$ and $\mathrm{EC}$ at Mt. Hua in summer were $43 \pm 17,3.5 \pm 1.3$ and $0.65 \pm 0.27 \mu \mathrm{g} \mathrm{m}^{-3}$, respectively, and lower than those in winter $(54 \pm 24,5.9 \pm 2.5$ and $0.9 \pm 0.6 \mu \mathrm{g} \mathrm{m}^{-3}$ ) (Li et al., 2012), mainly due to decreased emissions of biomass and coal burning for house heating. However, summertime meteorological conditions (e.g. higher temperatures and $\mathrm{RH}$ ) are favourable for secondary aerosol formation, resulting in higher concentrations of $\mathrm{SO}_{4}^{2-}$ and $\mathrm{NH}_{4}^{+}\left(21 \pm 12\right.$ and $4.3 \pm 2.5 \mu \mathrm{g} \mathrm{m}^{-3}$, respectively) in summer compared to those $(5.8 \pm 3.6$ and $1.6 \pm 0.9 \mu \mathrm{g} \mathrm{m}^{-3}$, respectively) in winter (Li et al., 2011).

Eight compounds were determined as oxidation products of isoprene in the $\mathrm{PM}_{10}$ samples, which are 3-MeTHF-3,4diols (the sum of trans-3-methyltetrahydrofuran-3,4-diol and cis-3-methyltetrahydrofuran-3,4-diol, $\quad 0.3 \pm 0.3 \mathrm{ng} \mathrm{m}^{-3}$ ), 2-methylglyceric acid $\left(4.1 \pm 2.2 \mathrm{ng} \mathrm{m}^{-3}\right), \mathrm{C}_{5}$-alkene triols (the sum of cis-2-methyl-1,3,4-trihydoxy-1-butane, 3methyl-2,3,4-trihydoxy-1-butane and trans-2-methyl-1,3,4trihydoxy-1-butane, $8.1 \pm 9.8 \mathrm{ng} \mathrm{m}^{-3}$ ) and 2-methyltetrols (the sum of 2-methylthreitol and 2-methylerythritol, $8.5 \pm 6.4 \mathrm{ng} \mathrm{m}^{-3}$ ) (Table 2 and Fig. 3) (Lin et al., 2012; Surratt et al., 2010). cis-Pinonic acid, 3-hydroxyglutaric acid and 3-methyl-1,2,3-butanetricarboxylic acid (MBTCA) are the major photooxidized products of $\alpha-/ \beta$-pinene, and their concentrations are $3.0 \pm 1.4,2.1 \pm 1.1$ and $1.6 \pm 1.1 \mathrm{ng} \mathrm{m}^{-3}$, respectively. $\beta$-Caryophyllinic acid, one of $\beta$-caryophyllene (a sesquiterpene) oxidation products, was also determined in this study, and its concentration was $2.2 \pm 1.2 \mathrm{ng} \mathrm{m}^{-3}$. Contributions of BVOCs to secondary organic carbon (SOC) in the atmosphere of Mt. Hua were estimated using a tracer-based method reported by Kleindienst et al. (2007). Concentrations of estimated isoprene, $\alpha-/ \beta$-pinene and $\beta$-caryophyllene derived SOC are $81 \pm 53,29 \pm 14$ and $98 \pm 53 \mathrm{ngC} \mathrm{m}^{-3}$, accounting for $2.7 \pm 1.0 \%, 0.8 \pm 0.2 \%$ and $2.1 \pm 1.0 \%$ of OC, respectively. It should be noted that the tracer-based method (Kleindienst et al., 2007) was developed under very limited experimental conditions of $\mathrm{NO}_{\mathrm{x}}$, aerosol acidity, and relative humidity. Moreover, the method neglects some BSOA tracers that are abundant as 2-methyltetrols in the Mt. Hua region, such as isoprene

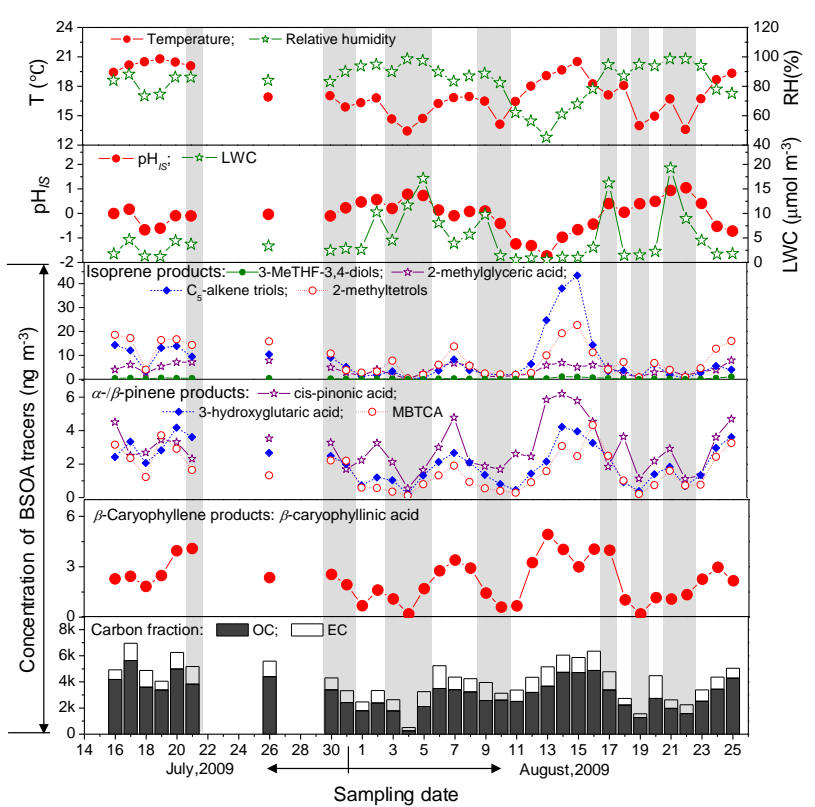

Fig. 3. Temporal variations of biogenic products, temperature, relative humidity, $\mathrm{pH}_{\mathrm{IS}}$ (in-situ acidity of particles), LWC (liquid water content of particles), OC and EC (organic and elemental carbon). The shadows denote rainy periods. 3MeTHF-3,4-diols: the sum of trans-3-methyltetrahydrofuran-3,4diol and cis-3-methyltetrahydrofuran-3,4-diol; MBTCA: 2-methyl1,2,3-butanetricarboxylic acid.

derived $\mathrm{C}_{5}$-alkene triols and 3-methyltetrahydrofuran3,4 -diols. Thus, the estimated isoprene, $\alpha-/ \beta$-pinene and $\beta$-caryophyllene derived SOC might be underestimated in the current study.

Succinic, glutaric and malic acids in the atmosphere are produced mainly by photochemical reactions of unsaturated hydrocarbons and fatty acids emitted from biomass burning and coal combustion (Kawamura and Yasui, 2005; Wang et al., 2010). Concentrations $\left(2.2-5.8 \mathrm{ng} \mathrm{m}^{-3}\right)$ of these compounds in the Mt. Hua $\mathrm{PM}_{10}$ samples are comparable to the BSOA tracers above. Phthalic acids are derived from photooxidation of polycyclic aromatic hydrocarbons (PAHs) (Simoneit et al., 2004b; Wang et al., 2007), and pyrolysis of plastic materials (Kawamura and Pavuluri, 2010). Their concentrations in the Mt. Hua samples are $0.16-4.9 \mathrm{ng} \mathrm{m}^{-3}$. Levoglucosan is a tracer of biomass burning, while arabitol is a metabolic product from pollen, spores, fungi, algae and bacteria (Engling et al., 2009; Simoneit et al., 2004a; Wang et al., 2009b, 2011b). Levoglucosan is lower in summer $\left(14 \pm 12 \mathrm{ng} \mathrm{m}^{-3}\right)$ than in winter $\left(65 \pm 30 \mathrm{ng} \mathrm{m}^{-3}\right)$, in contrast to arabitol $\left(5.5 \pm 3.5 \mathrm{ng} \mathrm{m}^{-3}\right.$ in summer and $3.0 \pm 2.0 \mathrm{ng} \mathrm{m}^{-3}$ in winter) (Li et al., 2012), indicating a decreased biomass burning and an increased biogenic activity in the hot season. 
Table 2. Concentrations (arithmetic mean \pm standard deviation, $\mathrm{ng} \mathrm{m}^{-3}$ ) and $t$ test results of the BSOA tracers and other compounds in the $\mathrm{PM}_{10}$ samples in Mt. Hua from southerly (S), easterly (E) and northerly (N) air masses.

\begin{tabular}{|c|c|c|c|c|c|c|c|}
\hline & \multicolumn{4}{|c|}{ Concentration } & \multicolumn{3}{|c|}{$p$ value $(t$ test $)$} \\
\hline & $\mathrm{S}(N=17)$ & $\mathrm{E}(N=11)$ & $\mathrm{N}(N=6)$ & Mean $(N=34)$ & S-E & $\mathrm{S}-\mathrm{N}$ & E-N \\
\hline \multicolumn{8}{|l|}{ I. Inorganic ions } \\
\hline$T\left(^{\circ}\right)$ & $18 \pm 2.1$ & $16 \pm 1.1$ & $18 \pm 2.2$ & $17 \pm 2.1$ & 0.002 & 0.230 & 0.372 \\
\hline $\mathrm{RH}(\%)$ & $85 \pm 10$ & $91 \pm 5.0$ & $64 \pm 13$ & $84 \pm 13$ & 0.036 & 0.022 & 0.032 \\
\hline $\mathrm{PM}_{10}\left(\mu \mathrm{g} \mathrm{m}^{-3}\right)$ & $42 \pm 17$ & $42 \pm 17$ & $46 \pm 6.6$ & $43 \pm 17$ & 0.664 & 0.808 & 0.609 \\
\hline $\mathrm{OC}\left(\mu \mathrm{g} \mathrm{m}^{-3}\right)$ & $4.0 \pm 1.2$ & $3.0 \pm 1.2$ & $3.0 \pm 0.87$ & $3.5 \pm 1.3$ & 0.019 & 0.127 & 0.612 \\
\hline $\mathrm{EC}\left(\mu \mathrm{g} \mathrm{m}^{-3}\right)$ & $0.65 \pm 0.26$ & $0.57 \pm 0.20$ & $0.78 \pm 0.37$ & $0.65 \pm 0.27$ & 0.790 & 0.567 & 0.746 \\
\hline $\mathrm{SO}_{4}^{2-}\left(\mu \mathrm{g} \mathrm{m}^{-3}\right)$ & $19 \pm 9.9$ & $23 \pm 11$ & $15 \pm 6.8$ & $21 \pm 12$ & 0.141 & 0.191 & 0.066 \\
\hline $\mathrm{NO}_{3}^{-}\left(\mu \mathrm{g} \mathrm{m}^{-3}\right)$ & $1.2 \pm 1.7$ & $1.5 \pm 1.3$ & $2.0 \pm 0.4$ & $1.4 \pm 1.4$ & 0.617 & 0.415 & 0.603 \\
\hline $\mathrm{NH}_{4}^{+}\left(\mu \mathrm{g} \mathrm{m}^{-3}\right)$ & $4.0 \pm 2.0$ & $5.1 \pm 2.5$ & $3.1 \pm 1.4$ & $4.3 \pm 2.5$ & 0.079 & 0.175 & 0.046 \\
\hline $\mathrm{Na}^{+}\left(\mu \mathrm{g} \mathrm{m}^{-3}\right)$ & $0.23 \pm 0.06$ & $0.30 \pm 0.13$ & $0.23 \pm 0.08$ & $0.23 \pm 0.07$ & 0.353 & 0.990 & 0.546 \\
\hline $\mathrm{K}^{+}\left(\mu \mathrm{g} \mathrm{m}^{-3}\right)$ & $0.28 \pm 0.13$ & $0.28 \pm 0.15$ & $0.20 \pm 0.12$ & $0.27 \pm 0.14$ & 0.079 & 0.175 & 0.046 \\
\hline $\mathrm{Mg}^{2+}\left(\mu \mathrm{g} \mathrm{m}^{-3}\right)$ & $0.10 \pm 0.05$ & $0.07 \pm 0.03$ & $0.15 \pm 0.06$ & $0.10 \pm 0.05$ & 0.903 & 0.229 & 0.279 \\
\hline $\mathrm{Ca}^{2+}\left(\mu \mathrm{g} \mathrm{m}^{-3}\right)$ & $0.40 \pm 0.27$ & $0.28 \pm 0.11$ & $0.70 \pm 0.27$ & $0.41 \pm 0.27$ & 0.211 & 0.028 & 0.002 \\
\hline $\mathrm{pH}_{\mathrm{IS}}^{\mathrm{a}}$ & $0.0 \pm 0.55$ & $0.30 \pm 0.39$ & $-1.08 \pm 0.47$ & $-0.08 \pm 0.64$ & 0.145 & 0.032 & 0.001 \\
\hline $\operatorname{LWC}^{\mathrm{a}}\left(\mu \mathrm{mol} \mathrm{m}^{-3}\right)$ & $4.85 \pm 5.27$ & $7.01 \pm 4.51$ & $0.93 \pm 0.34$ & $4.87 \pm 4.90$ & 0.197 & 0.113 & 0.001 \\
\hline \multicolumn{8}{|l|}{ II. Isoprene derived SOA } \\
\hline 3-MeTHF-3,4-diols ${ }^{b}$ & $0.43 \pm 0.29$ & $0.16 \pm 0.12$ & $0.13 \pm 0.08$ & $0.30 \pm 0.29$ & 0.002 & 0.001 & 0.438 \\
\hline 2-methylglyceric acid & $4.7 \pm 1.7$ & $3.9 \pm 2.4$ & $2.7 \pm 1.7$ & $4.1 \pm 2.2$ & 0.139 & 0.009 & 0.307 \\
\hline $\mathrm{C}_{5}$-alkene triolsb & $12 \pm 12$ & $3.9 \pm 3.1$ & $7.7 \pm 8.7$ & $8.1 \pm 9.8$ & 0.019 & 0.359 & 0.375 \\
\hline 2-methyltetrols ${ }^{\mathrm{b}}$ & $12 \pm 6.3$ & $6.1 \pm 4.8$ & $4.1 \pm 3.1$ & $8.5 \pm 6.4$ & 0.012 & 0.001 & 0.341 \\
\hline subtotal & $29 \pm 19$ & $14 \pm 10$ & $15 \pm 13$ & $21 \pm 17$ & 0.018 & 0.065 & 0.897 \\
\hline $\mathrm{SOC}_{\text {isoprene }}\left(\mathrm{ngC} \mathrm{m}^{-3}\right)^{\mathrm{c}}$ & $106 \pm 49$ & $65 \pm 45$ & $44 \pm 30$ & $81 \pm 53$ & 0.017 & 0.005 & 0.313 \\
\hline \multicolumn{8}{|l|}{ III. $\alpha-/ \beta$-pinene derived SOA } \\
\hline cis-pinonic acid & $3.3 \pm 1.4$ & $2.5 \pm 1.1$ & $3.1 \pm 1.4$ & $3.0 \pm 1.4$ & 0.083 & 0.387 & 0.656 \\
\hline 3-hydorxyglutaric acid & $2.6 \pm 1.1$ & $1.6 \pm 0.78$ & $1.4 \pm 0.67$ & $2.1 \pm 1.1$ & 0.009 & 0.008 & 0.371 \\
\hline MBTCA & $2.2 \pm 1.1$ & $1.0 \pm 0.64$ & $0.88 \pm 0.49$ & $1.6 \pm 1.1$ & 0.001 & 0.004 & 0.537 \\
\hline subtotal & $8.1 \pm 3.1$ & $5.1 \pm 2.3$ & $5.3 \pm 2.4$ & $6.6 \pm 3.3$ & 0.006 & 0.024 & 0.837 \\
\hline $\mathrm{SOC}_{\text {pinene }}\left(\mathrm{ngC} \mathrm{m}^{-3}\right)^{\mathrm{c}}$ & $35 \pm 13$ & $22 \pm 9.8$ & $23 \pm 10$ & $29 \pm 14$ & 0.006 & 0.024 & 0.837 \\
\hline \multicolumn{8}{|l|}{ IV. $\beta$-caryophyllene derived SOA } \\
\hline$\beta$-caryophyllinic acid & $2.7 \pm 1.1$ & $1.9 \pm 1.0$ & $2.3 \pm 1.6$ & $2.2 \pm 1.2$ & 0.056 & 0.255 & 0.903 \\
\hline SOC $_{\text {caryophyllene }}\left(\mathrm{ngC} \mathrm{m}^{-3}\right)^{\mathrm{c}}$ & $116 \pm 47$ & $81 \pm 42$ & $98 \pm 72$ & $98 \pm 53$ & 0.056 & 0.255 & 0.903 \\
\hline \multicolumn{8}{|l|}{ V. Other organic compounds } \\
\hline Succinic acid & $6.7 \pm 3.1$ & $6.8 \pm 3.5$ & $1.6 \pm 0.41$ & $5.8 \pm 3.6$ & 0.716 & 0.001 & 0.002 \\
\hline Glutaric acid & $2.4 \pm 1.0$ & $2.2 \pm 1.3$ & $0.88 \pm 0.31$ & $2.2 \pm 1.5$ & 0.295 & 0.007 & 0.013 \\
\hline Malic acid & $7.3 \pm 2.4$ & $5.1 \pm 2.6$ & $2.7 \pm 1.5$ & $5.8 \pm 3.2$ & 0.015 & 0.001 & 0.062 \\
\hline$o$-Phthalic acid & $6.2 \pm 2.3$ & $4.4 \pm 2.1$ & $2.9 \pm 1.5$ & $4.9 \pm 2.5$ & 0.026 & 0.002 & 0.165 \\
\hline$m$-Phthalic acid & $0.18 \pm 0.08$ & $0.13 \pm 0.06$ & $0.15 \pm 0.08$ & $0.16 \pm 0.08$ & 0.095 & 0.262 & 0.922 \\
\hline$p$-Phthalic acid & $2.7 \pm 2.2$ & $1.7 \pm 1.7$ & $3.0 \pm 3.0$ & $2.3 \pm 2.2$ & 0.189 & 0.915 & 0.439 \\
\hline Levoglucosan & $17 \pm 13$ & $12 \pm 12$ & $14 \pm 6.8$ & $14 \pm 12$ & 0.306 & 0.479 & 0.853 \\
\hline Arabitol & $6.1 \pm 4.0$ & $4.3 \pm 2.8$ & $5.9 \pm 0.63$ & $5.5 \pm 3.5$ & 0.494 & 0.645 & 0.894 \\
\hline
\end{tabular}


Table 3. Concentrations $\left(\mathrm{ng} \mathrm{m}^{-3}\right.$ ) of BSOA in Mt. Hua and other regions in the world during summer.

\begin{tabular}{|c|c|c|c|c|c|c|c|c|}
\hline Location & $\begin{array}{l}\text { Latitude } \\
\left({ }^{\circ}\right)\end{array}$ & $\begin{array}{l}\text { Aerosols } \\
\text { type }\end{array}$ & $\begin{array}{l}\text { Isoprene } \\
\text { products }\end{array}$ & $\begin{array}{l}\alpha \text {-/ } \beta \text {-pinene } \\
\text { products }\end{array}$ & $\begin{array}{l}\beta \text {-caryophyllene } \\
\text { products }\end{array}$ & $\begin{array}{l}\text { 2-methyltetrols } \\
\text {-C/OC }(\%)\end{array}$ & $R_{\mathrm{MBTCA} / \mathrm{PA}}$ & Reference \\
\hline Changbai, China & $42^{\circ} 24^{\prime} \mathrm{N}$ & $\mathrm{PM}_{2.5}$ & 53 & 31 & $\mathrm{NA}^{*}$ & 0.45 & NA & Wang et al. (2008) \\
\hline Mt. Tai, China & $36^{\circ} 41^{\prime} \mathrm{N}$ & TSP & 171 & 30 & 12 & 0.32 & 1.0 & Fu et al. (2010) \\
\hline Mt. Hua, China & $34^{\circ} 29^{\prime} \mathrm{N}$ & $\mathrm{PM}_{10}$ & 13 & 6.6 & 2.2 & 0.11 & 0.54 & This study \\
\hline Chongming, China & $30^{\circ} 50^{\prime} \mathrm{N}$ & $\mathrm{PM}_{2.5}$ & 48 & 1.8 & NA & 0.02 & NA & Wang et al. (2008) \\
\hline Dinghu, China & $23^{\circ} 10^{\prime} \mathrm{N}$ & $\mathrm{PM}_{2.5}$ & 26 & NA & NA & 0.17 & NA & Wang et al. (2008) \\
\hline Wangqingsha, China & $22^{\circ} 42^{\prime} \mathrm{N}$ & $\mathrm{PM}_{2.5}$ & 31 & 6.6 & 0.54 & 0.07 & 0.32 & Ding et al. (2011) \\
\hline Hong Kong, China & $22^{\circ} 13^{\prime} \mathrm{N}$ & $\mathrm{PM}_{2.5}$ & 30 & 198 & 13 & 0.24 & NA & Hu et al., (2008) \\
\hline Hainan, China & $18^{\circ} 40^{\prime} \mathrm{N}$ & $\mathrm{PM}_{2.5}$ & 51 & 9.4 & NA & 0.75 & NA & Wang et al. (2008) \\
\hline Alert, Canada & $82^{\circ} 30^{\prime} \mathrm{N}$ & TSP & 0.30 & 1.6 & 0.12 & 0.02 & 9.4 & Fu et al. (2009) \\
\hline Hyytiälä, Finland & $61^{\circ} 51^{\prime} \mathrm{N}$ & $\mathrm{PM}_{1}$ & 17 & 65 & NA & 0.25 & NA & Kourtchev et al. (2008a) \\
\hline Jülich, Germany & $50^{\circ} 54^{\prime} \mathrm{N}$ & $\mathrm{PM}_{2.5}$ & 21 & 26 & NA & 0.14 & NA & Kourtchev et al. (2008b) \\
\hline RTP, NC, USA & $35^{\circ} 54^{\prime} \mathrm{N}$ & $\mathrm{PM}_{2.5}$ & 137 & 153 & 11 & NA & NA & Lewandowski et al. (2007) \\
\hline S.E. USA & $30^{\circ} 26^{\prime} \mathrm{N}-33^{\circ} 56^{\prime} \mathrm{N}$ & $\mathrm{PM}_{2.5}$ & $40-1245$ & NA & NA & $0.52-7.0$ & NA & $\begin{array}{l}\text { Ding et al. (2008); } \\
\text { Lin et al. (2013b) }\end{array}$ \\
\hline An urban site in Mexico & $19^{\circ} 29^{\prime} \mathrm{N}$ & $\mathrm{PM}_{2.5}$ & 34 & 48 & 3.4 & 0.17 & 0.91 & Stone et al. (2010) \\
\hline A rural site in Mexico & $19^{\circ} 42^{\prime} \mathrm{N}$ & $\mathrm{PM}_{2.5}$ & 32 & 55 & 5.7 & 0.28 & 4.8 & Stone et al. (2010) \\
\hline Balbina, Brazil & $1^{\circ} 55^{\prime} \mathrm{S}$ & $\mathrm{PM}_{2.5}$ & 57 & NA & NA & 1.8 & NA & Claeys et al. (2004) \\
\hline
\end{tabular}

* NA: not available.

\subsubsection{Comparison between different air masses classified by backward trajectories analysis}

72-h backward trajectory analysis using the HYSPLIT Trajectory Model showed that air masses reaching the sampling site during the campaign were from three directions: southerly, easterly and northerly (Fig. 1). Thus, all the samples were categorized into the three groups and compared for the differences in concentrations and compositions (Table 2). A $t$-test comparing the mean values of concentrations was also conducted to explore whether the differences between the different air masses were statistically significant (Table 2). Nearly all of the anthropogenic species (e.g. EC, $\mathrm{SO}_{4}^{2-}, \mathrm{NO}_{3}^{-}, \mathrm{NH}_{4}^{+}$, phthalic acids and levoglucosan) presented a $p$ value larger than 0.05 , which statistically means there is no significant difference for these components between the three directions. However, most BSOA tracers presented higher concentrations for the southerly samples than those for the easterly and northerly samples with a $p$ value lower than 0.05 (Table 2), which is reasonable as plant vegetation is more abundant in the southern part of the Qinling mountains.

\subsubsection{Comparison of BSOA tracers with other studies}

A comparison of concentrations and diagnostic ratios of isoprene, $\alpha-/ \beta$-pinene and $\beta$-caryophyllene products is shown in Table 3. In this study, aerosol samples were collected at a summit of Mt. Hua (2060 m a.s.l), where vegetation is limited and the ground surfaces are mostly rocks. Thus, BSOA tracers present the lowest concentration in Mt. Hua compared to those in other areas except Alert $\left(82.5^{\circ} \mathrm{N}, 62.3^{\circ} \mathrm{W}\right)$ in the Canadian High Arctic region. All the tracers at the Alert site are 1-3 orders of magnitude lower than those in other regions. 2-Methyltetrols are the major products of isoprene (Claeys et al., 2010; Edney et al., 2005; Kleindienst et al., 2006); thus their contribution to organic carbon of airborne particles can be used roughly to compare the impact of isoprene-derived SOA relative to other OC sources. As shown in Table 3, the ratio of 2-methyltetrols-C/OC is highest in the equatorial region (Balbina, Brazil, 1.8\%) (Claeys et al., 2004) and southeastern USA (0.52-7.0\%) (Ding et al., 2008; Lin et al., 2013b), and lowest at the Arctic site (Alert, Canada 0.019\%) (Fu et al., 2009). Isoprene derived products are abundant in the southeastern USA region especially in rural areas, where concentrations of total detected isoprene SOA tracers can reach up to $1245 \mathrm{ng} \mathrm{m}^{-3}$ and their contribution to organic matters (OM) is more than $19 \%$ (Lin et al., 2013b). The carbon contribution of 2-methyltetrols in Mt. Hua $(0.11 \pm 0.06 \%)$ is lower than those $(0.17-0.75 \%$, Table 3) in other Chinese regions excluding Wangqingsha and Chongming, suggesting the lower impact of isoprenederived SOA relative to other sources. The lowest ratios in Wangqingsha $(0.070 \%)$ and Chongming $(0.020 \%)$ most likely result from the high anthropogenic OC input since both sites are close to urban areas.

MBTCA is a gas-phase oxidation product of cis-pinonic acid (PA) by $\mathrm{OH}$ radical (Henry and Donahue, 2012; Szmigielski et al., 2007). Thus the ratio of MBTCA/PA $\left(R_{\mathrm{MBTCA} / \mathrm{PA}}\right)$ is indicative of aerosol ageing (Kulmala et al., 2011). The ratios (0.54 and 1.0, Table 3) at Mt. Hua and Mt. Tai are higher than that (0.32, Table 3$)$ at Wangqingsha, a lowland rural site in southern China, indicating the mountain aerosols are more oxidized. Such a phenomenon may be related to the stronger mountaintop radiation that causes the BSOA to become highly oxidized. Averaged ratios of MBTCA/PA in Mt. Hua were $0.71 \pm 0.27,0.43 \pm 0.31$ and $0.29 \pm 0.12$ for the southerly, easterly and northerly samples, respectively, indicating that aerosols derived from the southerly air masses were more aged. A much higher MBTCA/PA ratio (4.8, Table 3) was found at a rural site in 
Mexico in comparison with that $(0.91$, Table 3$)$ in the Mexico urban region due to ageing (Stone et al., 2010), which is consistent with the larger contributions $(25 \pm 5 \%)$ of aged low molecular weight acids (mainly oxalic acid) to water-soluble organic carbon at the peripheral rural site than that in the urban area (Stone et al., 2010). Concentration of MBTCA at the Arctic site is almost one order of magnitude higher than PA (MBTCA/PA $=9.4$ at Alert, Table 3). Such spatial variations in the ratios indicate a continuous oxidation of BSOA during transport.

\subsection{In-situ pH and liquid water content of particles}

Chemical reaction in aerosol phase and gas-particle partitioning are strongly linked to the actual $\mathrm{pH}$ (i.e. in-situ $\mathrm{pH}, \mathrm{pH}_{\mathrm{IS}}$ ) of the aqueous phase and liquid water content (LWC) of particles (Xue et al., 2011). Thus, aerosol $\mathrm{pH}_{\mathrm{IS}}$ and LWC were calculated in this study using the following equation:

$\mathrm{pH}_{\mathrm{IS}}=-\log \alpha_{\mathrm{H}+}=-\log \left(\gamma_{\mathrm{H}+} \times n_{\mathrm{H}+} \times 1000 / V_{\mathrm{a}}\right)$

where $\alpha_{\mathrm{H}+}$ is activity of $\mathrm{H}^{+}$in $\mathrm{mol} \mathrm{L}^{-1}$ of the aqueous phase on the particle, $\gamma_{\mathrm{H}+}$ is the activity coefficient of $\mathrm{H}^{+}, n_{\mathrm{H}+}$ is free $\mathrm{H}^{+}$in the unit of $\mathrm{molm}^{-3}$ of air, and $V_{\mathrm{a}}$ is the volume concentration of the aqueous phase of aerosol in ambient atmosphere in the unit of $\mathrm{cm}^{3} \mathrm{~m}^{-3} \cdot \gamma_{\mathrm{H}_{+}}, n_{\mathrm{H}+}$ and $V_{\mathrm{a}}$ as well as LWC $\left(\mu \mathrm{mol} \mathrm{m}^{-3}\right)$ are derived using the Aerosol Inorganic Model (AIM) (Clegg et al., 1998a, b). As $\mathrm{SO}_{4}^{2-}, \mathrm{NO}_{3}^{-}$ and $\mathrm{NH}_{4}^{+}$are detected in this study, we chose the AIM-II model for calculation, which considers a $\mathrm{SO}_{4}^{2-}-\mathrm{NO}_{3}^{-}-\mathrm{NH}_{4}^{+}$$\mathrm{H}^{+}$system and allows variable temperature and relative humidity. As shown in Table 2, $\mathrm{pH}_{\mathrm{IS}}$ are $-0.08 \pm 0.64$ in $\mathrm{PM}_{10}$ at Mt. Hua, which is comparable with those in $\mathrm{PM}_{2.5}$ samples from Hong Kong $(-0.08 \pm 0.81$ during the summer of 2009) (Xue et al., 2011) but higher than those of $\mathrm{PM}_{2.5}$ at Qinghai Lake $(-1.20 \pm 0.32$ during the summer of 2010) (Li et al., 2013), a highland site with a distance of around $1000 \mathrm{~km}$ west to Mt. Hua. Total concentration of other cations (i.e. $\mathrm{Ca}^{2+}, \mathrm{Mg}^{2+}, \mathrm{Na}^{+}$and $\mathrm{K}^{+}$) is about $1.0 \mu \mathrm{g} \mathrm{m}^{-3}$ and not included in the model. Thus, the in-situ pH of the Mt. Hua samples might be overestimated, although the mineral ions are much less abundant than $\mathrm{NH}_{4}^{+}\left(4.3 \pm 2.5 \mu \mathrm{g} \mathrm{m}^{-3}\right)$ (Table 2). LWC $\left(0.93 \pm 0.34 \mu \mathrm{mol} \mathrm{m}^{-3}\right.$, Table 2$)$ of the particles from the northerly air masses is 5-8 times lower than that from the southerly and easterly air masses, which is probably related to the differences in relative humidity of the air masses and hygroscopicity of the particles.

\subsection{Effects of temperature on BSOA concentration}

Temporal variations of BSOA tracers, $\mathrm{OC}$ and EC in $\mathrm{PM}_{10}$ and meteorological conditions are shown in Fig. 3. The sharp declines of their concentrations during the rainy days possibly suggest a significant scavenging effect of wet deposition. The variations of the twelve BSOA tracers exhibit the same pattern, because they are formed via similar pathways.
The $\mathrm{PM}_{10}$ samples collected during the three different groups of air masses were explored for the correlations of BSOA with meteorological parameters (Fig. $4 \mathrm{a}-\mathrm{u}$ ), and the statistical results of the correlations are shown in Table S1. Nearly all of the detected BSOA tracers show a robust linear relation with ambient temperature, largely due to enhancements in BVOCs emission and BSOA production under higher temperature. Such a temperature dependence is also observed in other areas such as the central Pearl River Delta region, southern China (except 2-methylglyceric acid) (Ding et al., 2011) and Research Triangle Park, North Carolina, USA (Offenberg et al., 2011). As shown in Fig. 4c, the slopes of 2-methyltetrols concentration versus temperature in this study are $2.7,2.0$ and $0.79 \mathrm{ng} \mathrm{m}^{-3}{ }^{\circ} \mathrm{C}^{-1}$ for the $\mathrm{PM}_{10}$ samples from southerly, easterly and northerly air masses, respectively, much lower than that $\left(5.27 \mathrm{ng} \mathrm{m}^{-3}{ }^{\circ} \mathrm{C}^{-1}\right.$ ) (Ding et al., 2011) in southern China. This can be explained by a higher isoprene emission due to more abundant vegetation in the south lowland region (Guenther et al., 2006).

\subsection{Effects of relative humidity on BSOA concentration}

As far as we know, field observations of the influence of relative humidity $(\mathrm{RH})$ on SOA formation from biogenic VOCs were sparsely documented. Some chamber studies explored the effects of humidity on BSOA production. For example, Zhang et al. (2011) conducted a chamber study and found that 2-methylglyceric acid and its corresponding oligomers were enhanced in the particle-phase under lower RH conditions. In contrast, 2-methyltetrols did not substantially vary under different RH conditions. However, in this study we found that concentrations of all of the detected BSOA showed a significant negative linear correlation with relative humidity (Fig. 4h-n).

In fact, an enhancing effect of aerosol acidity on BSOA formation was found by several chamber and field studies (Ding et al., 2011; Iinuma et al., 2004; Offenberg et al., 2009). Surratt et al. (2010) found that isoprene epoxydiols (IEPOX) are key intermediates of SOA formation from isoprene under low- $\mathrm{NO}_{\mathrm{x}}$ conditions, which are initially formed in the gas-phase and subsequently partitioned into aerosol aqueous-phase. The aerosol phase IEPOX further converts to 2-methyltetrols and $\mathrm{C}_{5}$-alkene triols by an acid-catalyzed ring opening of this epoxydiol and a subsequent nucleophilic addition. Lin et al. (2012) again confirmed that IEPOX is taken up reactively onto acidified sulfate aerosols to produce 2-methylthreitol and 2-methylerythritol as well as other IEPOX-derived SOA tracers, including $\mathrm{C}_{5}$-alkene triols, 3methyltetrahydrofuran-3,4-diols, dimers, and organosulfates. Aerosol in-situ acidity is strongly dependent on relative humidity. Based on the AIM model calculations, we found that relative humidity $(\mathrm{RH})$ of the mountaintop atmosphere exhibits a robust linear correlation with the in-situ $\mathrm{pH}\left(\mathrm{pH}_{\mathrm{IS}}\right)$ of the $\mathrm{PM}_{10}$ particles $(R=0.97, p<0.05)$ and a moderate correlation with LWC of the particles $(R=0.80, p<0.05)$. As 

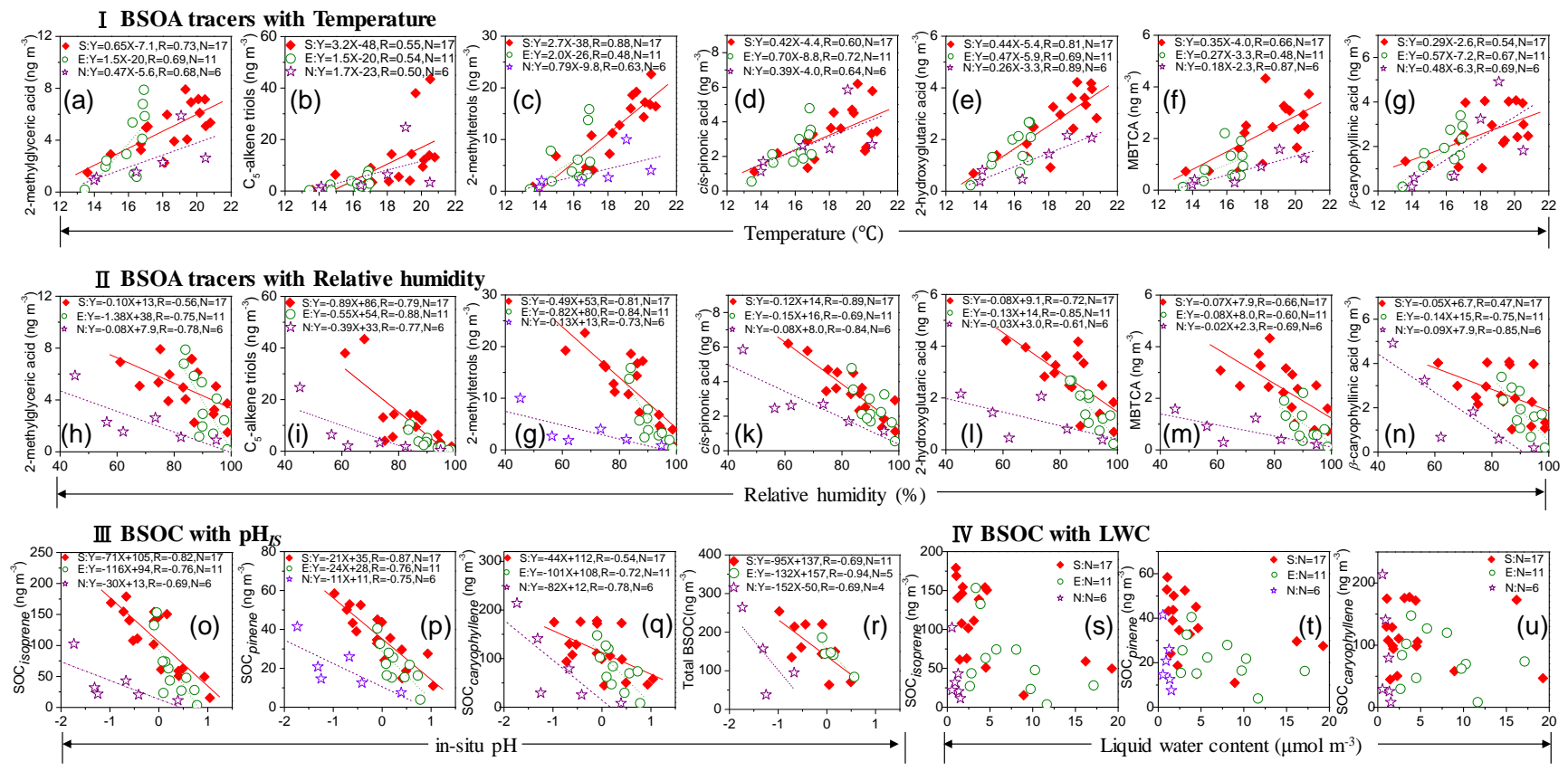

Fig. 4. Linear fit regressions of (a-g) BSOA tracers with temperature, (h-n) BSOA with relative humidity, (o-r) BSOC with in-situ pH (pHIS), and (s-u) BSOC with liquid water content (LWC). S, E, N: PM 10 aerosols from southerly (S), easterly (E) and northerly (N) air masses, respectively. MBTCA: 3-methyl-1,2,3-butanetricarboxylic acid. $\mathrm{SOC}_{\text {isoprene }}, \mathrm{SOC}_{\text {pinene }}$ and $\mathrm{SOC}_{\text {caryophellene }}$ the total mass concentrations of SOC (secondary organic carbon) produced by isoprene, $\alpha$-/ $\beta$-pinene, and $\beta$-caryophyllene were calculated using a tracerbased method reported by Kleindienst et al. (2007). Figure $4 \mathrm{r}$ excludes the samples collected on rainy days. All the values presented here are daily averages.

shown in Fig. 4o-q, concentrations of all the calculated SOC in the air masses showed a negative linear correlation with $\mathrm{pH}_{\mathrm{IS}}$, and the correlation was even stronger when the data of rainy days were excluded (Fig. 4r), which suggests that the suppressing effect of RH on BSOA formation is most likely related to reducing aerosol acidity. Similar studies have been performed in southeastern USA, although the AIM model for most samples was not applicable due to the aerosol either being fully neutralized or the RH being too low in the region (Budisulistiorini et al., 2013; Lin et al., 2013b). Interestingly, Budisulistiorini et al. (2013) found that the IEPOX-OA factor obtained by PMF (positive matrix factorization) analysis of ACSM (Aerosol Chemical Speciation Monitor) data also showed a moderate correlation $(R=0.5)$ with in situ acidity of particles.

Moreover, Zhang et al. (2011) reported that low RH conditions can improve isoprene-derived SOA yields by promoting particle phase organic esterification processes. Nguyen et al. (2011) also pointed out that the suppression of condensation and addition reactions are the most important chemical effects of the increased RH on BSOA formation. However, we found there was no clear correlation between biogenic SOC (BSOC) concentration and liquid water content (LWC) of the particles (Fig. 4s-u). High LWC is favorable for a conversion of BSOA precursors into aqueous phase and thus en- hances BSOA production. On the other hand, however, high LWC may reduce particle acidity, which is unfavorable for BSOA production. In addition, variations in RH may result in changes of BVOC emissions and thus change BSOA production. In any case, more chamber and field studies are warranted to understand the influence of RH on BSOA formation.

Phthalic acids are believed to be produced by the oxidation of naphthalene and other polycyclic aromatic hydrocarbons (Kawamura and Ikushima, 1993; Kawamura et al., 2005). Similar to BSOA formation, these anthropogenic SOA also showed a positive correlation with temperature $(R>0.6)$. A clear correlation between RH and concentration of phthalic acids was not observed in this study $(R<0.1)$. However, recent investigations indicated that the yields of SOA derived from some aromatic compounds (such as xylenes and toluene) positively correlated with the particle water content (Kamens et al., 2011; Zhou et al., 2011), suggesting an importance of LWC of particles (RH dependent) in anthropogenic SOA formation. No significant correlation between $\mathrm{BSOA}$ tracers and anthropogenic parameters (e.g. $\mathrm{EC}, \mathrm{SO}_{4}^{2-}$ and $\mathrm{NO}_{3}^{-}$) was found in the current study. 
Table 4. Concentration $\left(\mathrm{ng} \mathrm{m}^{-3}\right)$ and geometric mean diameters (GMD, $\left.\mu \mathrm{m}\right)$ of BSOA and other components in fine $(<2.1 \mu \mathrm{m})$ and coarse modes $(>2.1 \mu \mathrm{m})$.

\begin{tabular}{|c|c|c|c|c|}
\hline & \multicolumn{2}{|c|}{ Fine mode $(<2.1 \mu \mathrm{m})$} & \multicolumn{2}{|c|}{ Coarse mode $(>2.1 \mu \mathrm{m})$} \\
\hline & Concentration & $\mathrm{GMD}^{\mathrm{a}}$ & Concentration & $\mathrm{GMD}^{\mathrm{a}}$ \\
\hline Particle mass $\left(\mu \mathrm{g} \mathrm{m}^{-3}\right)$ & $26 \pm 3.7$ & $0.82 \pm 0.01$ & $20 \pm 3.9$ & $9.82 \pm 1.27$ \\
\hline $\mathrm{SO}_{4}^{2-}\left(\mu \mathrm{g} \mathrm{m}^{-3}\right)$ & $11 \pm 1.4$ & $0.89 \pm 0.03$ & $3.0 \pm 0.18$ & $10.0 \pm 1.51$ \\
\hline $\mathrm{NO}_{3}^{-}\left(\mu \mathrm{g} \mathrm{m}^{-3}\right)$ & $0.81 \pm 0.45$ & $0.58 \pm 0.17$ & $1.2 \pm 0.32$ & $9.41 \pm 2.06$ \\
\hline $\mathrm{NH}_{4}^{+}\left(\mu \mathrm{g} \mathrm{m}^{-3}\right)$ & $2.4 \pm 0.51$ & $0.90 \pm 0.04$ & $0.04 \pm 0.01$ & $5.97 \pm 2.01$ \\
\hline $\mathrm{Na}^{+}\left(\mu \mathrm{g} \mathrm{m}^{-3}\right)$ & $0.25 \pm 0.01$ & $0.80 \pm 0.03$ & $0.09 \pm 0.02$ & $3.63 \pm 0.04$ \\
\hline $\mathrm{K}^{+}\left(\mu \mathrm{g} \mathrm{m}^{-3}\right)$ & $0.13 \pm 0.03$ & $0.91 \pm 0.04$ & $0.02 \pm 0.01$ & $10.1 \pm 3.25$ \\
\hline $\mathrm{Mg}^{2+}\left(\mu \mathrm{g} \mathrm{m}^{-3}\right)$ & $0.08 \pm 0.01$ & $0.89 \pm 0.05$ & $0.08 \pm 0.02$ & $5.75 \pm 0.41$ \\
\hline $\mathrm{Ca}^{2+}\left(\mu \mathrm{g} \mathrm{m}^{-3}\right)$ & $0.25 \pm 0.07$ & $0.89 \pm 0.03$ & $0.36 \pm 0.21$ & $7.95 \pm 1.12$ \\
\hline \multicolumn{5}{|l|}{ I. Isoprene derived SOA } \\
\hline 3-MeTHF-3,4-diols & $0.28 \pm 0.03$ & $0.78 \pm 0.04$ & $0.05 \pm 0.01$ & $6.82 \pm 1.69$ \\
\hline 2-methylglyceric acid & $2.3 \pm 0.54$ & $0.87 \pm 0.01$ & $1.3 \pm 0.27$ & $8.77 \pm 2.68$ \\
\hline $\mathrm{C}_{5}$-alkene triols & $9.2 \pm 2.6$ & $0.84 \pm 0.03$ & $0.98 \pm 0.22$ & $6.34 \pm 1.62$ \\
\hline 2-methyltetrols & $10 \pm 1.2$ & $0.81 \pm 0.04$ & $3.2 \pm 0.9$ & $6.63 \pm 1.67$ \\
\hline \multicolumn{5}{|c|}{ II. $\alpha$ - $/ \beta$-pinene derived SOA } \\
\hline cis-pinonic acid & $1.6 \pm 0.57$ & $0.74 \pm 0.03$ & $2.4 \pm 0.81$ & $8.40 \pm 2.81$ \\
\hline 3-hydorxyglutaric acid & $1.6 \pm 0.32$ & $0.77 \pm 0.02$ & $\mathrm{ND}^{\mathrm{b}}$ & $\mathrm{ND}^{\mathrm{b}}$ \\
\hline MBTCA & $1.5 \pm 0.30$ & $0.80 \pm 0.04$ & $0.05 \pm 0.01$ & $2.70 \pm 0.00$ \\
\hline \multicolumn{5}{|c|}{ III. $\beta$-caryophyllene derived SOA } \\
\hline$\beta$-caryophyllinic acid & $1.2 \pm 0.10$ & $0.79 \pm 0.01$ & $\mathrm{ND}^{\mathrm{b}}$ & $\mathrm{ND}^{\mathrm{b}}$ \\
\hline \multicolumn{5}{|c|}{ III. Other organic compounds } \\
\hline Succinic acid & $4.9 \pm 0.97$ & $0.98 \pm 0.02$ & $12.0 \pm 0.54$ & $9.96 \pm 2.76$ \\
\hline Glutaric acid & $1.5 \pm 0.11$ & $0.88 \pm 0.04$ & $0.62 \pm 0.17$ & $9.22 \pm 2.93$ \\
\hline Malic acid & $5.5 \pm 0.95$ & $0.82 \pm 0.04$ & $0.47 \pm 0.15$ & $9.12 \pm 3.70$ \\
\hline$o$-Phthalic acid & $4.6 \pm 0.87$ & $0.76 \pm 0.03$ & $4.3 \pm 1.8$ & $9.76 \pm 3.11$ \\
\hline$m$-Phthalic acid & $0.11 \pm 0.01$ & $0.73 \pm 0.04$ & $0.04 \pm 0.01$ & $8.97 \pm 3.19$ \\
\hline$p$-Phthalic acid & $1.8 \pm 0.44$ & $0.72 \pm 0.06$ & $0.38 \pm 0.22$ & $9.52 \pm 5.94$ \\
\hline Levoglucosan & $11 \pm 1.1$ & $0.63 \pm 0.05$ & $1.3 \pm 0.11$ & $6.83 \pm 2.28$ \\
\hline Arabitol & $0.32 \pm 0.06$ & $0.68 \pm 0.08$ & $7.1 \pm 1.34$ & $8.21 \pm 2.78$ \\
\hline
\end{tabular}

${ }^{\text {a }} \log \mathrm{GMD}=\left(\Sigma C_{i} \log D p_{i}\right) / \Sigma C_{i}$, where $C_{i}$ is the concentration of compound in size $i$ and $D p_{i}$ is the geometric mean particle diameter collected on stage $i$ (Hinds, 1999).

b ND: not detected.

\subsection{Size distribution}

To further discuss the sources of the BSOA in the mountain atmosphere, detailed information of their size distribution was investigated. Table 4 shows the concentration and geometric mean diameters (GMD) of the detected organic aerosols and inorganic ions in the fine $(<2.1 \mu \mathrm{m})$ and coarse $(>2.1 \mu \mathrm{m})$ modes, and their concentrations as a function of sizes are plotted in Fig. 5.

3-MeTHF-3,4-diols, $\mathrm{C}_{5}$-alkene triols and 2-methyltetrols exhibit unimodal size distribution pattern with a peak at the size of $0.7-1.1 \mu \mathrm{m}$ (Fig. 5a, c and d). As mentioned above, IEPOX are key intermediates of isoprene oxidation products of 3-MeTHF-3,4-diols, $\mathrm{C}_{5}$-alkene triols and 2-methyltetrols under low- $\mathrm{NO}_{\mathrm{x}}$ conditions through heterogeneous reactions in aerosol-phase (Lin et al., 2012; Surratt et al., 2010). In contrast, 2-methylglyceric acid is formed via nucleophilic attack of water on the oxirane ring of 2-methyloxirane-2-carboxylic acid (methacrylic acid epoxide, MAE), which is produced by isoprene oxidation under high- $\mathrm{NO}_{\mathrm{x}}$ conditions (Lin et al., 2013a). 2-Methylglyceric acid in the Mt. Hua aerosols exhibits a bimodal size distribution pattern with a major peak in the fine mode $(<2.1 \mu \mathrm{m})$ and a minor peak in the coarse mode $(>2.1 \mu \mathrm{m})$ (Fig. 5b).

cis-Pinonic acid exhibits a bimodal pattern with a large peak in the coarse mode (>2.1 $\mu \mathrm{m}$ ) (Fig. 5e), in contrast to 3hydroxyglutaric acid and MBTCA, which only occur in the fine mode (Fig. $5 \mathrm{f}$ and g). Such distributions are consistent 

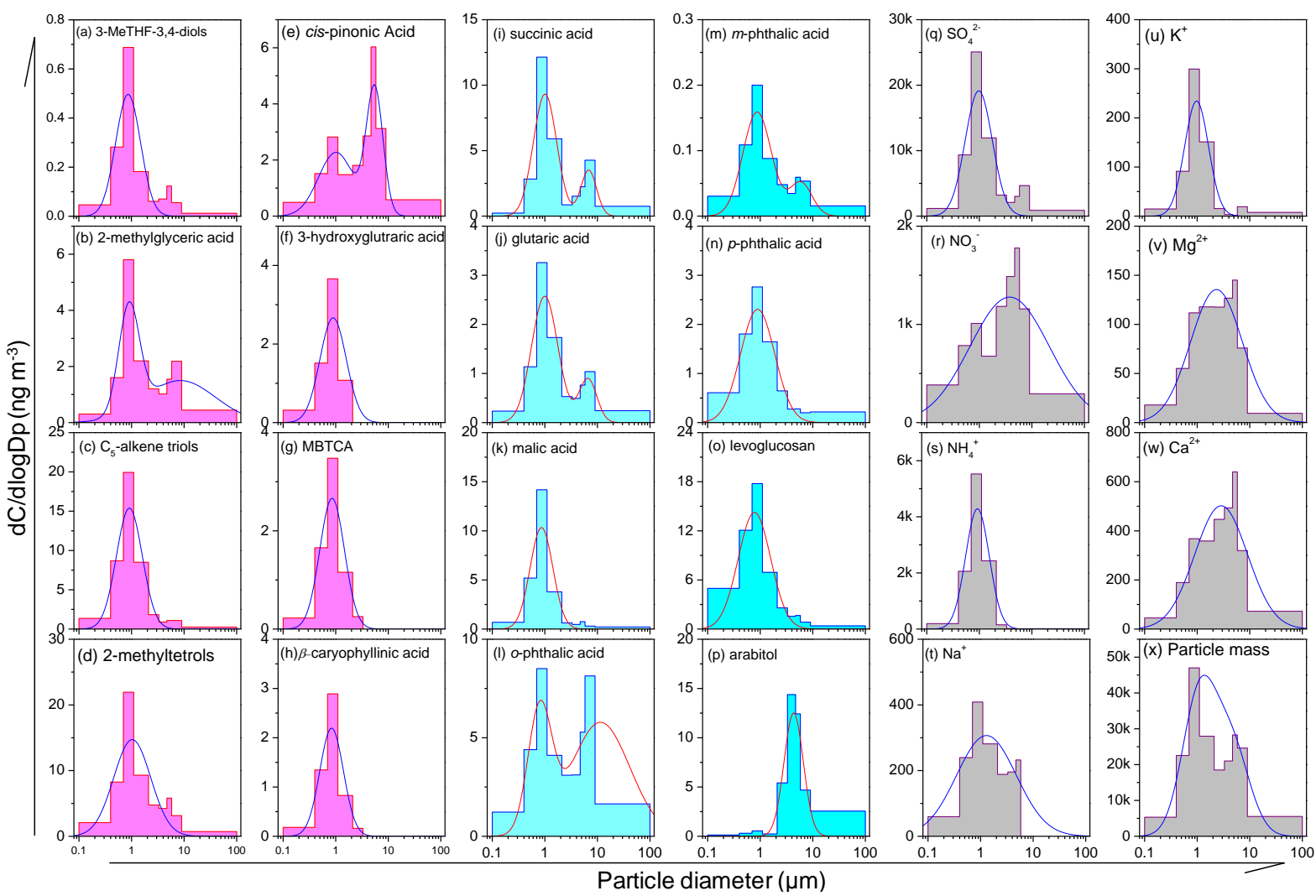

Fig. 5. Size distributions of (a-h) BSOA tracers, (i-p) other organic compounds, (q-w) inorganic ions, and (x) particle mass (3MeTHF-3,4-diols: the sum of trans-3-methyltetrahydrofuran-3,4-diol and cis-3-methyltetrahydrofuran-3,4-diol; MBTCA: 2-methyl-1,2,3butanetricarboxylic acid).

with those in Mainz, Germany (Zhang et al., 2010). cisPinonic acid is formed by a gas-phase oxidation of pinene with ozone and a subsequent adsorption onto pre-existing particles (Hallquist et al., 2009). On the contrary, MBTCA is likely formed in the gas phase by reactions of cis-pinonic acid or cis-pinic acid involving participation of $\mathrm{OH}$ radical (Jaoui et al., 2005; Szmigielski et al., 2007). The differences in size distributions of cis-pinonic acid and MBTCA can be ascribed to the highly volatile nature of $c i s$-pinonic acid. Zhang et al. (2010) pointed out that cis-pinonic acid is predominantly present in the gas phase. Coarse particle are generally basic, because they are in most cases enriched with mineral species. Therefore, cis-pinonic acid in gas-phase may prefer to reactively uptake onto coarse particles. Only a fine mode of $\beta$-caryophyllinic acid was observed in the mountain atmosphere (Fig. 5h).

Succinic and glutaric acids are formed mostly from anthropogenic volatile organic compounds, which are firstly oxidized as gaseous keto-carboxylic acids and then partitioned into particle phase followed by a further oxidation to dicarboxylic acids (Wang et al., 2011a). Thus both show a bimodal size distribution (Fig. $5 \mathrm{i}$ and j). On the contrary, malic acid is found to be mostly produced in biomass combustion process and emitted into the air as fine particles (Wang et al., 2011a, 2012), thus malic acid showed a fine mode pattern (Fig. 5k). o-Phthalic acid is formed via a gaseous oxidation of naphthalene and followed by a subsequent adsorption/condensation onto pre-existing particles, thus, showed a bimodal pattern (Fig. 51), in contrast to a unimodal pattern of $p$-phthalic acid (Fig. $5 \mathrm{n}$ ), which is largely formed by a pyrolysis of plastic materials and emitted into the air as fine particles (Wang et al., 2012). Levoglucosan, a key tracer for biomass burning, presents a unimodal distribution, peaking at a size of $0.7-1.1 \mu \mathrm{m}$ in summer (Fig. 5o). In contrast, arabitol is dominated in coarse particle as it mostly originates from pollen, spore and other biota (Fig. 5p). $\mathrm{SO}_{4}^{2-}$ and $\mathrm{NH}_{4}^{+}$ in the Mt. Hua samples are predominant in the fine mode (Fig. 5q and s) in summer, similar to those in winter ( $\mathrm{Li}$ et al., 2011). However, coarse particles in the mountain atmosphere are more enriched in $\mathrm{NO}_{3}^{-}$compared to that in Xi' an (unreported data), a mega-city near Mt. Hua (Fig. 5r). Such a shift to large particles is caused by an evaporation of nitrate from fine particles and a subsequent adsorption onto coarse particles during the air mass transport onto the mountaintop. $\mathrm{Na}^{+}$and $\mathrm{K}^{+}$are predominant in fine particles in the Mt. Hua region (Fig. 5t and u), suggesting they are mainly 
derived from biomass burning instead of soil resuspension. $\mathrm{Ca}^{2+}$ and $\mathrm{Mg}^{2+}$ are the tracers of dust emission, and thus they are abundant in coarse particles (Fig. $5 \mathrm{v}$ and w).

\section{Summary and conclusion}

BSOA derived from isoprene, pinene and sesquiterpene were determined for $\mathrm{PM}_{10}$ and size-resolved aerosols collected at the mountaintop of Mt. Hua. Backward trajectories analysis showed that nearly all the BSOA tracers were present at higher concentrations in the samples from the southerly than those from the easterly and northerly, indicating higher BVOC emissions and/or more BSOA production. Concentrations of the BSOA in the mountain samples increased with an increase in temperature during the campaign, because higher temperature is favorable for BVOCs emission and subsequent oxidation. In contrast, RH showed significant linear negative correlations with concentrations of all the isoprene, pinene and caryophyllene products. Based on the AIM model calculation, we found that an increase in RH can result in a decrease in particle in-situ acidity, which reduces the effect of acid-catalysis on BSOA formation. However, such a significant relation was not observed for LWC and BSOA. Furthermore, no significant correlation between the BSOA tracers and anthropogenic species (such as $\mathrm{EC}, \mathrm{SO}_{4}^{2-}$ and $\mathrm{NO}_{3}^{-}$) was found. Size distribution details were also explored for the target compounds. Most of the BSOA are enriched in the fine mode $(<2.1 \mu \mathrm{m})$ except for cis-pinonic acid, which is dominated in the coarse mode $(>2.1 \mu \mathrm{m})$ due to its highly volatile nature. Size distributions of levoglucosan, arabitol and other secondary aerosols were also investigated. These size distribution details are helpful for recognising their atmospheric fate including formation, adsorption and evaporation.

\section{Supplementary material related to this article is available online at http://www.atmos-chem-phys.net/13/ 11535/2013/acp-13-11535-2013-supplement.pdf.}

Acknowledgements. This work was financially supported by the "Strategic Priority Research Program" of the Chinese Academy of Sciences (Grant No. XDA05100103, XDB05020401), China National Science Funds for Distinguished Young Scholars (N0. 41325014), and the Ministry of Science \& Technology of China (2007BAC30B00, 2012BAH31B00). We thank the AIM Model group for using the AIM model (Simon L. Clegg and Peter Brimblecombe, University of East Anglia, and Anthony S. Wexler, University of California-Davis, http://www.aim.env.uea.ac.uk/aim/aim.php). We also thank the anonymous reviewers and Meiling Gao in Department of Environmental Health Sciences, School of Public Health, UC-Berkeley for their comments on this work that are very helpful for us to improve the paper quality.

Edited by: B. Ervens

\section{References}

Budisulistiorini, S. H., Canagaratna, M. R., Croteau, P. L., Marth, W. J., Baumann, K., Edgerton, E. S., Shaw, S. L., Knipping, E. M., Worsnop, D. R., Jayne, J. T., Gold, A., and Surratt, J. D.: Real-Time Continuous Characterisation of Secondary Organic Aerosol Derived from Isoprene Epoxydiols in Downtown Atlanta, Georgia, Using the Aerodyne Aerosol Chemical Speciation Monitor, Environ. Sci. Technol., 47, 5686-5694, 2013.

Chow, J. C., Watson, J. G., Chen, L. W. A., Arnott, W. P., and Moosmuller, H.: Equivalence of elemental carbon by thermal/optical reflectance and transmittance with different temperature protocols, Environ. Sci. Technol., 38, 4414-4422, 2004.

Claeys, M., Graham, B., Vas, G., Wang, W., Vermeylen, R., Pashynska, V., Cafmeyer, J., Guyon, P., Andreae, M. O., Artaxo, P., and Maenhaut, W.: Formation of secondary organic aerosols through photooxidation of isoprene, Science, 303, 1173-1176, 2004.

Claeys, M., Kourtchev, I., Pashynska, V., Vas, G., Vermeylen, R., Wang, W., Cafmeyer, J., Chi, X., Artaxo, P., Andreae, M. O., and Maenhaut, W.: Polar organic marker compounds in atmospheric aerosols during the LBA-SMOCC 2002 biomass burning experiment in Rondonia, Brazil: sources and source processes, time series, diel variations and size distributions, Atmos. Chem. Phys., 10, 9319-9331, doi:10.5194/acp-10-9319-2010, 2010.

Clegg, S. L., Brimblecombe, P., and Wexler, A. S.: Thermodynamic model of the system H+-NH4+-Na+-SO42-NB3-Cl-H2O at 298.15 K, J. Phys. Chem. A, 102, 2155-2171, 1998a.

Clegg, S. L., Brimblecombe, P., and Wexler, A. S.: Thermodynamic model of the system $\mathrm{H}+-\mathrm{NH} 4+-\mathrm{SO}_{4}^{2-}-\mathrm{NO}_{3}^{-}-\mathrm{H}_{2} \mathrm{O}$ at tropospheric temperatures, J. Phys. Chem. A, 102, 2137-2154, 1998 b.

Ding, X., Zheng, M., Yu, L., Zhang, X., Weber, R. J., Yan, B., Russell, A. G., Edgerton, E. S., and Wang, X.: Spatial and Seasonal Trends in Biogenic Secondary Organic Aerosol Tracers and Water-Soluble Organic Carbon in the Southeastern United States, Environ. Sci. Technol., 42, 5171-5176, 2008.

Ding, X., Wang, X.-M., and Zheng, M.: The influence of temperature and aerosol acidity on biogenic secondary organic aerosol tracers: Observations at a rural site in the central Pearl River Delta region, South China, Atmos. Environ., 45, 1303-1311, 2011.

Eddingsaas, N. C., Loza, C. L., Yee, L. D., Chan, M., Schilling, K. A., Chhabra, P. S., Seinfeld, J. H., and Wennberg, P. O.: $\alpha$-pinene photooxidation under controlled chemical conditions - Part 2: SOA yield and composition in low- and high-NOx environments, Atmos. Chem. Phys., 12, 7413-7427, doi:10.5194/acp-12-74132012, 2012.

Edney, E. O., Kleindienst, T. E., Jaoui, M., Lewandowski, M., Offenberg, J. H., Wang, W., and Claeys, M.: Formation of 2-methyl tetrols and 2-methylglyceric acid in secondary organic aerosol from laboratory irradiated isoprene/ $\mathrm{NO}(\mathrm{X}) / \mathrm{SO}(2) /$ air mixtures and their detection in ambient $\operatorname{PM}(2.5)$ samples collected in the eastern United States, Atmos. Environ., 39, 5281-5289, 2005.

Engling, G., Lee, J. J., Tsai, Y. W., Lung, S. C. C., Chou, C. C. K., and Chan, C. Y.: Size-Resolved Anhydrosugar Composition 
in Smoke Aerosol from Controlled Field Burning of Rice Straw, Aerosol Sci. Technol., 43, 662-672, 2009.

Fang, M., Chan, C. K., and Yao, X. H.: Managing air quality in a rapidly developing nation: China, Atmos. Environ., 43, 79-86, 2009.

Froyd, K. D., Murphy, S. M., Murphy, D. M., de Gouw, J. A., Eddingsaas, N. C., and Wennberg, P. O.: Contribution of isoprenederived organosulfates to free tropospheric aerosol mass, P. Natl. Acad. Sci. USA, 107, 21360-21365, 2010.

Fu, P. Q., Kawamura, K., Chen, J., and Barrie, L. A.: Isoprene, Monoterpene, and Sesquiterpene Oxidation Products in the High Arctic Aerosols during Late Winter to Early Summer, Environ. Sci. Technol., 43, 4022-4028, 2009.

Fu, P. Q., Kawamura, K., Kanaya, Y., and Wang, Z. F.: Contributions of biogenic volatile organic compounds to the formation of secondary organic aerosols over Mt Tai, Central East China, Atmos. Environ., 44, 4817-4826, 2010.

Fu, Z., Zhng, X., Liou, S., and Tao, M.: The Sumarize of Research on the Flora and Vegetation of the Qin Lin Mountain Range (in Chinese), Acta Botanica Boreali-Occidentalia Sinica, 1996, 93 106, 1996.

Guenther, A., Karl, T., Harley, P., Wiedinmyer, C., Palmer, P. I., and Geron, C.: Estimates of global terrestrial isoprene emissions using MEGAN (Model of Emissions of Gases and Aerosols from Nature), Atmos. Chem. Phys., 6, 3181-3210, doi:10.5194/acp-63181-2006, 2006.

Hallquist, M., Wenger, J. C., Baltensperger, U., Rudich, Y., Simpson, D., Claeys, M., Dommen, J., Donahue, N. M., George, C., Goldstein, A. H., Hamilton, J. F., Herrmann, H., Hoffmann, T., Iinuma, Y., Jang, M., Jenkin, M. E., Jimenez, J. L., Kiendler-Scharr, A., Maenhaut, W., McFiggans, G., Mentel, Th. F., Monod, A., Prévôt, A. S. H., Seinfeld, J. H., Surratt, J. D., Szmigielski, R., and Wildt, J.: The formation, properties and impact of secondary organic aerosol: current and emerging issues, Atmos. Chem. Phys., 9, 5155-5236, doi:10.5194/acp-9-51552009, 2009.

Henry, K. M. and Donahue, N. M.: Photochemical Aging of alpha-Pinene Secondary Organic Aerosol: Effects of OH Radical Sources and Photolysis, J. Phys. Chem. A, 116, 5932-5940, 2012.

Hinds, W. C.: Aerosol Technology: Properties, Behavior, and Measurement of Airborne Particles, John Wiley and Sons, New York, 1999.

Hu, D., Bian, Q., Li, T. W. Y., Lau, A. K. H., and Yu, J. Z.: Contributions of isoprene, monoterpenes, beta-caryophyllene, and toluene to secondary organic aerosols in Hong Kong during the summer of 2006, J. Geophys. Res.-Atmos., 113, D22206, doi:10.1029/2008JD010437, 2008.

Iinuma, Y., Boge, O., Gnauk, T., and Herrmann, H.: Aerosolchamber study of the alpha-pinene/O-3 reaction: influence of particle acidity on aerosol yields and products, Atmos. Environ., 38, 761-773, 2004.

Jaoui, M., Kleindienst, T. E., Lewandowski, M., Offenberg, J. H., and Edney, E. O.: Identification and quantification of aerosol polar oxygenated compounds bearing carboxylic or hydroxyl groups. 2. Organic tracer compounds from monoterpenes, Environ. Sci. Technol., 39, 5661-5673, 2005.

Jaoui, M., Edney, E. O., Kleindienst, T. E., Lewandowski, M., Offenberg, J. H., Surratt, J. D., and Seinfeld, J. H.: For- mation of secondary organic aerosol from irradiated alphapinene/toluene/ $\mathrm{NO}(\mathrm{x})$ mixtures and the effect of isoprene and sulfur dioxide, J. Geophys. Res.-Atmos., 113, D09303, doi:10.1029/2007JD009426, 2008.

Kamens, R. M., Zhang, H., Chen, E. H., Zhou, Y., Parikh, H. M., Wilson, R. L., Galloway, K. E., and Rosen, E. P.: Secondary organic aerosol formation from toluene in an atmospheric hydrocarbon mixture: Water and particle seed effects, Atmos. Environ., 45, 2324-2334, 2011.

Kanakidou, M., Seinfeld, J. H., Pandis, S. N., Barnes, I., Dentener, F. J., Facchini, M. C., Van Dingenen, R., Ervens, B., Nenes, A., Nielsen, C. J., Swietlicki, E., Putaud, J. P., Balkanski, Y., Fuzzi, S., Horth, J., Moortgat, G. K., Winterhalter, R., Myhre, C. E. L., Tsigaridis, K., Vignati, E., Stephanou, E. G., and Wilson, J.: Organic aerosol and global climate modelling: a review, Atmos. Chem. Phys., 5, 1053-1123, doi:10.5194/acp-5-1053-2005, 2005.

Kawamura, K. and Ikushima, K.: Seasonal changes in the distribution of dicarboxylic acids in the urban atmosphere, Environ. Sci. Technol., 27, 2227-2235, 1993.

Kawamura, K. and Pavuluri, C. M.: New Directions: Need for better understanding of plastic waste burning as inferred from high abundance of terephthalic acid in South Asian aerosols, Atmos. Environ., 44, 5320-5321, 2010.

Kawamura, K. and Yasui, O.: Diurnal changes in the distribution of dicarboxylic acids, ketocarboxylic acids and dicarbonyls in the urban Tokyo atmosphere, Atmos. Environ., 39, 1945-1960, 2005.

Kawamura, K., Imai, Y., and Barrie, L. A.: Photochemical production and loss of organic acids in high Arctic aerosols during longrange transport and polar sunrise ozone depletion events, Atmos. Environ., 39, 599-614, 2005.

Kleindienst, T. E.: Epoxying Isoprene Chemistry, Science, 325 687-688, 2009.

Kleindienst, T. E., Edney, E. O., Lewandowski, M., Offenberg, J. H., and Jaoui, M.: Secondary organic carbon and aerosol yields from the irradiations of isoprene and alpha-pinene in the presence of $\mathrm{NO}_{\mathrm{x}}$ and SO2, Environ. Sci. Technol., 40, 3807-3812, 2006

Kleindienst, T. E., Jaoui, M., Lewandowski, M., Offenberg, J. H., Lewis, C. W., Bhave, P. V., and Edney, E. O.: Estimates of the contributions of biogenic and anthropogenic hydrocarbons to secondary organic aerosol at a southeastern US location, Atmos. Environ., 41, 8288-8300, 2007.

Kourtchev, I., Ruuskanen, T. M., Keronen, P., Sogacheva, L., Dal Maso, M., Reissell, A., Chi, X., Vermeylen, R., Kulmala, M., Maenhaut, W., and Claeys, M.: Determination of isoprene and $\alpha-/ \beta$-pinene oxidation products in boreal forest aerosols from Hyytiälä, Finland: diel variations and possible link with particle formation events, Plant Biol., 10, 138-149, 2008a.

Kourtchev, I., Warnke, J., Maenhaut, W., Hoffmann, T., and Claeys, M.: Polar organic marker compounds in PM2.5 aerosol from a mixed forest site in western Germany, Chemosphere, 73, 13081314, 2008b.

Kulmala, M., Asmi, A., Lappalainen, H. K., Baltensperger, U., Brenguier, J.-L., Facchini, M. C., Hansson, H.-C., Hov, Ø., O'Dowd, C. D., Pöschl, U., Wiedensohler, A., Boers, R., Boucher, O., de Leeuw, G., Denier van der Gon, H. A. C., Feichter, J., Krejci, R., Laj, P., Lihavainen, H., Lohmann, U., McFiggans, G., Mentel, T., Pilinis, C., Riipinen, I., Schulz, M., 
Stohl, A., Swietlicki, E., Vignati, E., Alves, C., Amann, M., Ammann, M., Arabas, S., Artaxo, P., Baars, H., Beddows, D. C. S., Bergström, R., Beukes, J. P., Bilde, M., Burkhart, J. F., Canonaco, F., Clegg, S. L., Coe, H., Crumeyrolle, S., D’Anna, B., Decesari, S., Gilardoni, S., Fischer, M., Fjaeraa, A. M., Fountoukis, C., George, C., Gomes, L., Halloran, P., Hamburger, T., Harrison, R. M., Herrmann, H., Hoffmann, T., Hoose, C., Hu, M., Hyvärinen, A., Hõrrak, U., Iinuma, Y., Iversen, T., Josipovic, M., Kanakidou, M., Kiendler-Scharr, A., Kirkevåg, A., Kiss, G., Klimont, Z., Kolmonen, P., Komppula, M., Kristjánsson, J.-E., Laakso, L., Laaksonen, A., Labonnote, L., Lanz, V. A., Lehtinen, K. E. J., Rizzo, L. V., Makkonen, R., Manninen, H. E., McMeeking, G., Merikanto, J., Minikin, A., Mirme, S., Morgan, W. T., Nemitz, E., O’Donnell, D., Panwar, T. S., Pawlowska, H., Petzold, A., Pienaar, J. J., Pio, C., Plass-Duelmer, C., Prévôt, A. S. H., Pryor, S., Reddington, C. L., Roberts, G., Rosenfeld, D., Schwarz, J., Seland, Ø., Sellegri, K., Shen, X. J., Shiraiwa, M., Siebert, H., Sierau, B., Simpson, D., Sun, J. Y., Topping, D., Tunved, P., Vaattovaara, P., Vakkari, V., Veefkind, J. P., Visschedijk, A., Vuollekoski, H., Vuolo, R., Wehner, B., Wildt, J., Woodward, S., Worsnop, D. R., van Zadelhoff, G.-J., Zardini, A. A., Zhang, K., van Zyl, P. G., Kerminen, V.-M., S Carslaw, K., and Pandis, S. N.: General overview: European Integrated project on Aerosol Cloud Climate and Air Quality interactions (EUCAARI) - integrating aerosol research from nano to global scales, Atmos. Chem. Phys., 11, 13061-13143, doi:10.5194/acp11-13061-2011, 2011.

Lewandowski, M., Jaoui, M., Kleindienst, T. E., Offenberg, J. H., and Edney, E. O.: Composition of PM2.5 during the summer of 2003 in Research Triangle Park, North Carolina, Atmos. Environ., 41, 4073-4083, 2007.

Li, J. J., Wang, G. H., Zhou, B. H., Cheng, C. L., Cao, J. J., Shen, Z. X., and An, Z. S.: Chemical composition and size distribution of wintertime aerosols in the atmosphere of Mt. Hua in central China, Atmos. Environ., 45, 1251-1258, 2011.

Li, J. J., Wang, G. H., Zhou, B. H., Cheng, C. L., Cao, J. J., Shen, Z. X., and An, Z. S.: Airborne particulate organics at the summit (2060 ma.s.1.) of Mt. Hua in central China during winter: Implications for biofuel and coal combustion, Atmos. Res., 106, 108-119, 2012.

Li, J. J., Wang, G. H., Wang, X. M., Cao, J. J., Sun, T., Cheng, C. L., Meng, J. J., Hu, T. F., and Liu, S. X.: Abundance, composition and source of atmospheric PM2.5 at a remote site in the Tibetan Plateau, China, Tellus B, 65, 20281, doi:10.3402/tellusb.v65i0.20281, 2013.

Lin, Y. H., Zhang, Z. F., Docherty, K. S., Zhang, H. F., Budisulistiorini, S. H., Rubitschun, C. L., Shaw, S. L., Knipping, E. M., Edgerton, E. S., Kleindienst, T. E., Gold, A., and Surratt, J. D.: Isoprene Epoxydiols as Precursors to Secondary Organic Aerosol Formation: Acid-Catalyzed Reactive Uptake Studies with Authentic Compounds, Environ. Sci. Technol., 46, 250-258, 2012.

Lin, Y.-H., Zhang, H., Pye, H. O. T., Zhang, Z., Marth, W. J., Park, S., Arashiro, M., Cui, T., Budisulistiorini, S. H., Sexton, K. G., Vizuete, W., Xie, Y., Luecken, D. J., Piletic, I. R., Edney, E. O., Bartolotti, L. J., Gold, A., and Surratt, J. D.: Epoxide as a precursor to secondary organic aerosol formation from isoprene photooxidation in the presence of nitrogen oxides, P. Natl. Acad. Sci., 110, 6718-6723, 2013a.
Lin, Y.-H., Knipping, E. M., Edgerton, E. S., Shaw, S. L., and Surratt, J. D.: Investigating the influences of $\mathrm{SO}_{2}$ and $\mathrm{NH}_{3}$ levels on isoprene-derived secondary organic aerosol formation using conditional sampling approaches, Atmos. Chem. Phys., 13, $8457-$ 8470, doi:10.5194/acp-13-8457-2013, 2013b.

Nguyen, T. B., Roach, P. J., Laskin, J., Laskin, A., and Nizkorodov, S. A.: Effect of humidity on the composition of isoprene photooxidation secondary organic aerosol, Atmos. Chem. Phys., 11, 6931-6944, doi:10.5194/acp-11-6931-2011, 2011.

Offenberg, J. H., Lewandowski, M., Edney, E. O., Kleindienst, T. E., and Jaoui, M.: Influence of Aerosol Acidity on the Formation of Secondary Organic Aerosol from Biogenic Precursor Hydrocarbons, Environ. Sci. Technol., 43, 7742-7747, 2009.

Offenberg, J. H., Lewandowski, M., Jaoui, M., and Kleindienst, T. E.: Contributions of Biogenic and Anthropogenic Hydrocarbons to Secondary Organic Aerosol during 2006 in Research Triangle Park, NC, Aerosol and Air Quality Research, 11, 99-U15, 2011.

Shen, Z. X., Arimoto, R., Cao, J. J., Zhang, R. J., Li, X. X., Du, N., Okuda, T., Nakao, S., and Tanaka, S.: Seasonal Variations and Evidence for the Effectiveness of Pollution Controls on WaterSoluble Inorganic Species in Total Suspended Particulates and Fine Particulate Matter from Xi' an, China, J. Air Waste Manage. Assoc., 58, 1560-1570, 2008.

Simoneit, B. R. T., Elias, V. O., Kobayashi, M., Kawamura, K., Rushdi, A. I., Medeiros, P. M., Rogge, W. F., and Didyk, B. M.: Sugars - Dominant water-soluble organic compounds in soils and characterisation as tracers in atmospheric particulate matter, Environ. Sci. Technol., 38, 5939-5949, 2004a.

Simoneit, B. R. T., Kobayashi, M., Mochida, M., Kawamura, K., and Huebert, B. J.: Aerosol particles collected on aircraft flights over the northwestern Pacific region during the ACE-Asia campaign: Composition and major sources of the organic compounds, J. Geophys. Res.-Atmos., 109, D19S09, doi:10.1029/2004jd004565, 2004b.

Stone, E. A., Hedman, C. J., Zhou, J., Mieritz, M., and Schauer, J. J.: Insights into the nature of secondary organic aerosol in Mexico City during the MILAGRO experiment 2006, Atmos. Environ., 44, 312-319, 2010.

Surratt, J. D., Chan, A. W. H., Eddingsaas, N. C., Chan, M. N., Loza, C. L., Kwan, A. J., Hersey, S. P., Flagan, R. C., Wennberg, P. O., and Seinfeld, J. H.: Reactive intermediates revealed in secondary organic aerosol formation from isoprene, P. Natl. Acad. Sci. USA, 107, 6640-6645, 2010.

Szmigielski, R., Surratt, J. D., Gomez-Gonzalez, Y., Van der Veken, P., Kourtchev, I., Vermeylen, R., Blockhuys, F., Jaoui, M., Kleindienst, T. E., Lewandowski, M., Offenberg, J. H., Edney, E. O., Seinfeld, J. H., Maenhaut, W., and Claeys, M.: 3-methyl1,2,3-butanetricarboxylic acid: An atmospheric tracer for terpene secondary organic aerosol, Geophys. Res. Lett., 34, L24811, doi:10.1029/2004jd004565, 2007.

Turpin, B. J. and Huntzicker, J. J.: Identification of secondary organic aerosol episodes and quantitation of primary and secondary organic aerosol concentrations during SCAQS, Atmos. Environ., 29, 3527-3544, 1995.

van Donkelaar, A., Martin, R. V., Brauer, M., Kahn, R., Levy, R., Verduzco, C., and Villeneuve, P. J.: Global Estimates of Ambient Fine Particulate Matter Concentrations from Satellite-Based Aerosol Optical Depth: Development and Application, Environ. Health Perspect., 118, 847-855, 2010. 
Wang, G. H., Kawamura, K., Lee, S., Ho, K. F., and Cao, J. J.: Molecular, seasonal, and spatial distributions of organic aerosols from fourteen Chinese cities, Environ. Sci. Technol., 40, 46194625, 2006.

Wang, G. H., Kawamura, K., Hatakeyama, S., Takami, A., Li, H., and Wang, W.: Aircraft measurement of organic aerosols over China, Environ. Sci. Technol., 41, 3115-3120, 2007.

Wang, G., Kawamura, K., Xie, M., Hu, S., Gao, S., Cao, J., An, Z., and Wang, Z.: Size-distributions of n-alkanes, PAHs and hopanes and their sources in the urban, mountain and marine atmospheres over East Asia, Atmos. Chem. Phys., 9, 8869-8882, doi:10.5194/acp-9-8869-2009, 2009a.

Wang, G. H., Kawamura, K., Umemoto, N., Xie, M. J., Hu, S. Y., and Wang, Z. F.: Water-soluble organic compounds in PM2.5 and size-segregated aerosols over Mount Tai in North China Plain, J. Geophys. Res.-Atmos., 114, D19208, doi:10.1029/2008jd011390, 2009b.

Wang, G., Xie, M., Hu, S., Gao, S., Tachibana, E., and Kawamura, K.: Dicarboxylic acids, metals and isotopic compositions of $\mathrm{C}$ and $\mathrm{N}$ in atmospheric aerosols from inland China: implications for dust and coal burning emission and secondary aerosol formation, Atmos. Chem. Phys., 10, 6087-6096, doi:10.5194/acp-106087-2010, 2010.

Wang, G. H., Chen, C. L., Li, J. J., Zhou, B. H., Xie, M. J., Hu, S. Y., Kawamura, K., and Chen, Y.: Molecular composition and size distribution of sugars, sugar-alcohols and carboxylic acids in airborne particles during a severe urban haze event caused by wheat straw burning, Atmos. Environ., 45, 2473-2479, $2011 \mathrm{a}$.

Wang, G. H., Kawamura, K., Xie, M. J., Hu, S. Y., Li, J. J., Zhou, B. H., Cao, J. J., and An, Z. S.: Selected water-soluble organic compounds found in size-resolved aerosols collected from urban, mountain and marine atmospheres over East Asia, Tellus B, 63, 371-381, 2011b.
Wang, G. H., Kawamura, K., Cheng, C. L., Li, J. J., Cao, J. J., Zhang, R. J., Zhang, T., Liu, S. X., and Zhao, Z. Z.: Molecular Distribution and Stable Carbon Isotopic Composition of Dicarboxylic Acids, Ketocarboxylic Acids, and alpha-Dicarbonyls in Size-Resolved Atmospheric Particles From Xi' an City, China, Environ. Sci. Technol., 46, 4783-4791, 2012.

Wang, W., Wu, M. H., Li, L., Zhang, T., Liu, X. D., Feng, J. L., Li, H. J., Wang, Y. J., Sheng, G. Y., Claeys, M., and Fu, J. M.: Polar organic tracers in $\mathrm{PM}_{2.5}$ aerosols from forests in eastern China, Atmos. Chem. Phys., 8, 7507-7518, doi:10.5194/acp-87507-2008, 2008.

Xue, J., Lau, A. K. H., and Yu, J. Z.: A study of acidity on PM2.5 in Hong Kong using online ionic chemical composition measurements, Atmos. Environ., 45, 7081-7088, 2011.

Zhang, H., Surratt, J. D., Lin, Y. H., Bapat, J., and Kamens, R. M.: Effect of relative humidity on SOA formation from isoprene/NO photooxidation: enhancement of 2-methylglyceric acid and its corresponding oligoesters under dry conditions, Atmos. Chem. Phys., 11, 6411-6424, doi:10.5194/acp-11-6411-2011, 2011.

Zhang, Y. Y., Müller, L., Winterhalter, R., Moortgat, G. K., Hoffmann, T., and Pöschl, U.: Seasonal cycle and temperature dependence of pinene oxidation products, dicarboxylic acids and nitrophenols in fine and coarse air particulate matter, Atmos. Chem Phys., 10, 7859-7873, doi:10.5194/acp-10-7859-2010, 2010.

Zhou, Y., Zhang, H., Parikh, H. M., Chen, E. H., Rattanavaraha, W., Rosen, E. P., Wang, W., and Kamens, R. M.: Secondary organic aerosol formation from xylenes and mixtures of toluene and xylenes in an atmospheric urban hydrocarbon mixture: Water and particle seed effects (II), Atmos. Environ., 45, 3882-3890, 2011. 